Please do not remove this page

RMIT

UNIVERSITY

\title{
Oxaliplatin-based chemotherapy combined with traditional medicines for neutropenia in colorectal cancer: A meta-analysis of the contributions of specific plants
}

Chen, Meng; May, Brian; Zhou, Iris Wenyu; Sze, Man Yuen Daniel; Xue, Charlie Changli; Zhang, Anthony Lin https://researchrepository.rmit.edu.au/esploro/outputs/9921860585701341/filesAndLinks?institution=61RMIT_INST\&index=null

Chen, M., May, B., Zhou, I. W., Sze, M. Y. D., Xue, C. C., \& Zhang, A. L. (2016). Oxaliplatin-based chemotherapy combined with traditional medicines for neutropenia in colorectal cancer: A meta-analysis of the contributions of specific plants. Critical Reviews in Oncology/Hematology, 105, 18-34. https://doi.org/10.1016/j.critrevonc.2016.07.002

Document Version: Accepted Manuscript

Published Version: https://doi.org/10.1016/j.critrevonc.2016.07.002

Repository homepage: https://researchrepository.rmit.edu.au

(C) 2016 Elsevier Ireland Ltd.

Downloaded On 2023/04/26 13:04:53 +1000 
Thank you for downloading this document from the RMIT Research Repository.

The RMIT Research Repository is an open access database showcasing the research outputs of RMIT University researchers.

RMIT Research Repository: http://researchbank.rmit.edu.au/

\section{Citation:}

Chen, M, May, B, Zhou, I, Sze, M, Xue, C and Zhang, A 2016, 'Oxaliplatin-based chemotherapy combined with traditional medicines for neutropenia in colorectal cancer: A meta-analysis of the contributions of specific plants', Critical Reviews in Oncology/Hematology, vol. 105, pp. 18-34.

See this record in the RMIT Research Repository at:

https://researchbank.rmit.edu.au/view/rmit:42363

Version:Accepted Version

\section{Copyright Statement:}

(C) 2016 This work is licensed under a Creative Commons Attribution-NonCommercialNoDerivatives 4.0 International License.

Link to Published Version:

https://dx.doi.org/10.1016/j.critrevonc.2016.07.002 


\section{Accepted Manuscript}

Title: Oxaliplatin-based chemotherapy combined with traditional medicines for neutropenia in colorectal cancer: A meta-analysis of the contributions of specific plants

Author: Menghua Chen Brian H. May Iris W. Zhou Daniel

Man-yuen Sze Charlie C. Xue<ce:author id="aut0030"

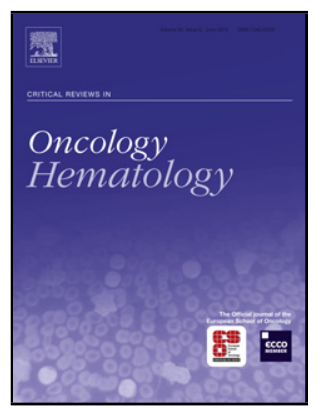

biographyid="vt0030" orcid="0000-0002-0968-9380">

Anthony L. Zhang

PII:

S1040-8428(16)30157-3

DOI:

http://dx.doi.org/doi:10.1016/j.critrevonc.2016.07.002

Reference:

ONCH 2222

To appear in: $\quad$ Critical Reviews in Oncology/Hematology

Received date: $\quad 30-10-2015$

Revised date: 6-5-2016

Accepted date: $\quad$ 6-7-2016

Please cite this article as: $\{\mathrm{http} / / / \mathrm{dx} . \mathrm{doi} . o r g /$

This is a PDF file of an unedited manuscript that has been accepted for publication. As a service to our customers we are providing this early version of the manuscript. The manuscript will undergo copyediting, typesetting, and review of the resulting proof before it is published in its final form. Please note that during the production process errors may be discovered which could affect the content, and all legal disclaimers that apply to the journal pertain. 


\section{Oxaliplatin-based chemotherapy combined with traditional medicines for neutropenia in colorectal cancer: a meta- analysis of the contributions of specific plants}

Menghua Chen $\mathrm{BMed}^{1}$, Brian $\mathrm{H}_{\text {May }} \mathrm{PhD}^{1}$, Iris W Zhou $\mathrm{PhD}^{1}$, Daniel Man-yuen Sze $\mathrm{PhD}^{1}$, Charlie C Xue $\mathrm{PhD}^{1,2}$, Anthony L Zhang $\mathrm{PhD}^{1 \S}$.

${ }^{1}$ The China-Australia International Research Centre for Chinese Medicine, School of Health and Biomedical Sciences, RMIT University, Bundoora, VIC 3083, Australia

${ }^{2}$ Guangdong Provincial Academy of Chinese Medical Sciences \& Guangdong Provincial Hospital of Chinese Medicine, Guangzhou, China

${ }^{\S}$ Corresponding author:

Dr Anthony L Zhang

The China-Australia International Research Centre for Chinese Medicine

School of Health and Biomedical Sciences, RMIT University, PO Box 71, Bundoora, Vic. 3083, Australia

Tel: +613 99257758, Fax: +61399257178

E-mail: tony.zhang@rmit.edu.au

Email addresses of other authors (note: mailing address is as above for all authors):

Menghua Chen BMed: PhD candidate, RMIT University, aussway@yahoo.com.au

Brian H May PhD: Clinical Research Fellow, RMIT University, brian.may@ rmit.edu.au

Daniel Man-yuen Sze PhD: Senior Lecturer, RMIT University, daniel.sze@ @mit.edu.au

Iris W Zhou PhD: Research Fellow, RMIT University, wenyu.zhou@rmit.edu.au

Charlie C Xue PhD: Executive Dean, School of Health and Biomedical Sciences, RMIT

University, charlie.xue@rmit.edu.au 


\section{Highlights}

- Combining oxaliplatin regimens with certain traditional medicine interventions in CRC appears to reduce CIN incidence.

- For the five plants associated with the greatest CIN reductions, experimental studies have reported effects on myelosuppression and/or immune response.

- These plants and their constituents warrant further investigation as sources of potential interventions for CIN.

\section{Contents}

$\begin{array}{ll}\text { 1. Introduction } & 7\end{array}$

$\begin{array}{lr}\text { 2. Method } & 8\end{array}$

2.1. Subgroup analyses $\quad$ ' 9

2.2. Sensitivity analyses of orally administered TM interventions 9

$\begin{array}{ll}\text { 2.3. Selection of plants for further research } & 10\end{array}$

$\begin{array}{lr}\text { 3. Results } & 14\end{array}$

3.1. Methodological assessment 14

3.2. Meta-analysis of change in CIN 14

3.2.1. Injection group (no G-CSF) 15

3.2.2. Oral administration group (no G-CSF) 15

3.2.3. G-CSF group 15

$\begin{array}{ll}\text { 3.2.4. Neutrophil count } & 15\end{array}$

3.3. Effect of number of cycles of chemotherapy on CIN incidence 19

3.4. Meta-analysis of tumour response rate (tRR) 19

3.5 Effects of individual plant-based ingredients in orally administered TMs 19

3.5.1 Level 1: Single plants 23

3.5.2 Level 2: Pairs of plants 23

3.5.3 Level 3: Combinations of three plants 23

3.5.4 Level 4: Combinations of four plants 23

3.5.5 Level 5: Combinations of five plants 23

3.5.6 Level 6: Combinations of six plants 23 
3.6. TMs with consistent results at multiple levels $\quad 24$

3.7. Potential synergistic effects of TMs 24

4. Discussion $\quad 24$

4.1. Limitations of the study 25

4.2. Effects of the five selected plants in experimental models 25

4.3. Is there any evidence for synergistic effects? 28

$\begin{array}{lr}\text { 5. Conclusions } & 29\end{array}$

6. Acknowledgments 30

$\begin{array}{ll}\text { 7. Funding support } & 30\end{array}$

8. Conflict of interest disclosure 30

9. Authors' contributions 30

10. References 31

$\begin{array}{ll}\text { 11. Biographies } & 40\end{array}$

$\begin{array}{ll}\text { 12. Figure captions } & 41\end{array}$

13. Highlights 43

\begin{abstract}
This review assessed the effects on chemotherapy induced neutropenia (CIN) of combining oxaliplatin regimens with traditional plant-based medicines (TMs) in the management of colorectal cancer (CRC). 32 RCTs (2,224 participants) were included. Meta-analysis showed reduced incidence of grade $3 / 4 \mathrm{CIN}$ (RR $0.45[0.31,0.65], \mathrm{I}^{2}=0 \%$ ). No studies reported serious adverse events or reduction in tumour response rates associated with concurrent use of oxaliplatin and TM. Due to small sample sizes and risk of bias, these results should be interpreted with caution. Analyses of sub-groups of studies that used similar TM interventions assessed the relative contributions of individual plant-based ingredients to the results. Astragalus, Codonopsis, Atractylodes, Poria and Coix, in various combinations were consistently associated with reduced CIN incidence when administered orally. Experimental studies of these plants have reported reduced myelosuppression and/or enhanced immune
\end{abstract}


response. Further studies of these plants may lead to the development of interventions to supplement conventional CIN treatment.

\section{Abbreviations}

5-FU: 5-fluorouracil

AEs: adverse events

ANC: absolute neutrophil count

APS: Astragalus polysaccharides

BMSC: bone marrow stromal cells

CFU-F: colony-forming unit-fibroblast

CIN: chemotherapy induced neutropenia

CNKI: China Academic Journals

CQVIP: Chinese Science and Technology Journals

CRC: colorectal cancer

FN: febrile neutropenia

FOLFOX: 5-fluorouracil (5-FU) plus leucovorin (LV) combined with oxaliplatin

G-CSF: granulocyte colony-stimulating factor

GM-CSF: Granulocyte-macrophage colony-stimulating factor

KPS: Karnofsky Performance Status

LV: leucovorin

MD: mean difference

NCI-CTC: National Cancer Institute Common Toxicity Criteria

RCT: randomized controlled trial

RE: random effect model

RR: risk ratio

TMs: traditional medicines

WHO: World Health Organisation

XELOX: capecitabine plus oxaliplatin 


\section{Key words}

meta-analysis, natural products, myelosuppression, chemotherapy induced neutropenia, colorectal cancer, oxaliplatin

\section{Submission declaration}

This research has not been published previously and is not under submission, in whole or in part, to other journals.

\section{Introduction}

Colorectal cancer (CRC) is the second most common cancer in women and the third most common in men. In 2012 the World Health Organisation reported there were 1.4 million new cases and 694,000 deaths worldwide from CRC. This was an increase in both incidence rate and mortality compared with the 2010 study [1]. Oxaliplatin is a third generation platinum drug which inhibits DNA repair and replication, resulting in cell death [2]. In CRC treatment, standard chemotherapies in both adjuvant and palliative settings use oxaliplatin combined with 5-Fluorouracil (5-FU) or Leucovorin (LV)(referred to as FOLFOX), or oxaliplatin with oral capecitabine which converts to 5-FU in the body (referred to as XELOX)[3,4].

Chemotherapy induced neutropenia (CIN) is a decline in absolute neutrophil count (ANC) as a result of myelosuppression induced by systematic chemotherapy [5]. Neutropenia can lead to life-threatening infections so it is common practice to decrease dose intensity or cut short treatment cycles when serious neutropenia is evident but this will directly affect the effectiveness of the chemotherapy [6]. CIN severity is classified into four grades based on decline in ANC [7]. Febrile neutropenia (FN) is a serious condition that combines elevated body temperature, sepsis and severe neutropenia [7,8]. Risk factors for CIN include age, performance status, nutritional status, chemotherapy dose intensity, and low baseline blood cell counts [9].

CIN is one of the most common adverse reactions in CRC treatment using oxaliplatin regimens [10]. In CRC clinical trials the incidence of grade 3/4 CIN was found to vary from $37 \%$ to $56 \%$ in different populations [11] and CIN incidence has been found to be higher in regimens that combine oxaliplatin with 5-FU compared to single 5-FU regimens $[12,13]$. This may be associated with oxaliplatin reducing 5-FU plasma clearance by inhibiting 5-FU catabolism [14].

Granulocyte colony-stimulating factor (G-CSF) initiates the proliferation of granulocyte precursor cells and their differentiation into mature granulocytes in bone marrow. Clinical trials have found that recombinant G-CSF significantly reduced the incidence of grade 3/4 CIN and accelerated cancer patients' recovery from CIN after chemotherapy, thereby making higher-intensity treatment regimens possible [15-18]. In the past, G-CSF treatment was 
expensive [19] but the advent of biosimilars has made G-CSF support for CIN/FN prophylaxis more cost-effective [20].

With the aim of reducing adverse events (AEs) and improving clinical outcomes, some clinicians combine chemotherapy with traditional plant-based medicines (TMs) [21]. Several reviews have reported that chemotherapy combined with TMs could reduce AEs including CIN in various cancers [22-24]. In advanced CRC, a meta-analysis of RCT results showed FOLFOX 4 combined with TMs reduced grade $3 / 4$ CIN by $8.7 \%$ compared to FOLFOX 4 alone [25]. Some plants frequently used in the TMs, including Astragalus membranaceus (Fisch.) Bge., Panax ginseng C.A. Meyer, Atractylodes macrocephala Koidz., Poria cocos (Schw) Wolf and Coix lachry-jojobi L., have been reported to produce immunomodulatory effects in experimental studies [26-29]. These effects may, at least partially, account for the reported clinical benefits but it remains unclear which, if any, of these TMs could reduce the incidence of CIN when combined with chemotherapy for CRC.

In this review, we aimed to: 1 . assess the clinical trial literature on the effects of TMs on CIN associated with the use of oxaliplatin regimens for CRC; 2 . identify which TMs, or combinations of TMs, were associated with CIN alleviation when used in combination with oxaliplatin regimens in the clinical trials; and 3. identify directions for further clinical and experimental research.

We conducted a meta-analysis of randomized controlled trials (RCTs) of TMs combined with oxaliplatin regimens for CRC which reported data on CIN incidence. Then we used sensitivity analyses of sub-groups of studies that used the same or similar TM interventions to assess the potential contributions of individual plant-based ingredients to the meta-analysis results. For the plants that appeared most likely to be contributing to reduced CIN incidence, we reviewed the experimental literature to identify possible mechanisms of action.

\section{Method}

The following databases were searched: PubMed, EMBASE, Cochrane CENTRAL, CINAHL, Science Direct, PsycINFO, China Academic Journals (CNKI) and Chinese Science and Technology Journals (CQVIP). Search terms were in three groups: 1. Disease: colorectal cancer and related terms; 2. Intervention type: traditional medicine, herbal medicine, complementary medicine, and related terms; and 3. Study type: controlled trial, randomized and related terms. Hand-searches were conducted of reference lists in review articles and additional Chinese language journals (see Supp 1 for terms used for PubMed and list of journal that were hand searched). There were no restrictions on language or publication year.

Participants were adults over 18 years who had been diagnosed with CRC based on pathology tests and had undergone chemotherapy using an oxaliplatin regimen. No other restriction was placed on the age, gender or performance status of participants. Included studies were RCTs of an oxaliplatin regimen combined with a concurrent TM intervention in the test group compared with the same oxaliplatin regimen in the control group. The TM interventions contained natural products and could be administered systemically by any administration route. Studies that employed G-CSF were analysed separately. All RCTs reported on CIN (neutropenia or leucopenia) as an outcome measure. Studies that only reported on myelosuppression, or reported data in a form unsuitable for analysis were excluded. 
Records were kept of the numbers of studies at each stage in the search and selection process. These were summarised in a flowchart according to the PRISMA guidelines. Two reviewers (M.Chen \& I.Zhou) independently extracted data. Risk of Bias (RoB) was assessed by MC and IZ with mediation by A. Zhang. RoB included selection bias, performance bias, detection bias, attrition bias, and reporting bias. For each study, each domain was judged 'low risk', 'high risk' or 'not reported' when the information was not mentioned or incomplete.

Meta-analysis was conducted using Review Manager (RevMan) 5.1 as Risk Ratio (RR) or Mean Difference (MD) with 95\% confidence intervals (95\% CI) using random effects models. Incidence rates were expressed as the percentage of the number of participants with CIN in the group divided by the total number of the participants in the group. Studies with zero events were included to avoid overestimation of effect [31]. Proportion of heterogeneity was measured using $\mathrm{I}^{2}$. If $\mathrm{I}^{2}$ was over $50 \%$, indicating important heterogeneity, sensitivity analyses were performed to explore the sources of heterogeneity. Publication bias was assessed using a funnel plot [32] Effect of number of cycles of chemotherapy on CIN incidence was calculated using mean incidence rate (\%) with the standard error (SE).

\subsection{Subgroup analyses}

Subgroup analyses were planned for route of TM administration - intravenous (IV) or oral and studies employing G-CSF. Data analysis for CIN was stratified by: FN, CIN grade 4, CIN grade 3, CIN grade $3 / 4, \mathrm{CIN}$ grade $1 / 2$, and CIN all grades. To determine if the addition of the TMs affected the effectiveness of the chemotherapy, meta-analysis of tumour response rate (tRR) was conducted for the studies in the groups for CIN grade 3/4 and all grades.

\subsection{Sensitivity analyses of orally administered TM interventions}

For studies of multi-ingredient orally administered TM interventions further sensitivity analyses were planned based on the composition of the TM interventions. We reasoned that if a particular ingredient was effective (or ineffective) in alleviating neutropenia, this would be reflected in the pooled RR outcomes of the studies that employed this ingredient in the intervention. Therefore, by investigating the pooled RR of studies that used the same ingredient, or same combination of ingredients, we could identify those that showed potential for further research into interventions for neutropenia alleviation.

The following approach was used. Firstly, TM interventions which had plant-based ingredients in common were identified. Then, sensitivity analyses were conducted for groups of TM interventions that contained the same ingredients to determine which plants, and combinations of plants, produced greater or lesser changes in RR values for CIN all grades. The following multi-level procedure was used:

Level 1. Single plants present in two or more TM interventions were identified and the pooled RR was calculated for each subgroup of studies that contained the same plant as an ingredient. The pooled RRs (95\% CI and $\mathrm{I}^{2}$ ) were listed in ascending order and any significant results were noted. Plants that had significant results that did not show important heterogeneity ( $\mathrm{I}^{2}$ not greater than $30 \%$ ) were considered for higher level combinations. 
Level 2. Plants that had significant results at level 1 were paired with other plants that showed significant results at level 1 to produce a matrix of results. The RRs of the pairs were listed in ascending order and any significant results were noted.

Level 3 and above. Pairs of plants present at level 2 that had significant results were combined with other plants from level 1 to produce combinations of 3, 4 and more plants as the data set allowed. The pooled RRs of these combinations were listed in ascending order and any significant results were noted.

This procedure produces groups of studies that have, one, two and more plants as common ingredients in the TM interventions.

Only actual combinations of plants that were present in the oral TM interventions were included. For example, although plant 1 could be paired with plant 2 in the data matrix, all the TM interventions that contained plant $1+$ plant 2 may also have included plant 3 . In such cases, the RR of TM interventions in this group of studies actually reflects the combination of all 3 plants (as well as any other plants present), so there is no independent contribution to the RR from plant $1+$ plant 2 at Level 2. Therefore this pair was excluded from Level 2. Instead, the group, plant $1+$ plant $2+$ plant 3, was included in the RR matrix at Level 3 .

\subsection{Selection of plants for further research}

To select plants for further research, the following selection criteria were used: 1 . the RR of the group of two or more studies that contained the same plant(s) in the TM interventions was significantly decreased relative to controls; 2 . the RR was equal or lesser than the total pooled RR for the multi-ingredient oral TM interventions; 3 . lack of important heterogeneity ( $\mathrm{I}^{2}$ not greater than 30\%); and 4:the plant appeared at multiple levels of combination with consistently significant $R R$ results. When combinations of plants produced RRs that were lower than those of the plants individually, these were identified as possible examples of a synergistic effect.

\section{Results}

The searches located 2,648 potentially relevant citations and searches of reference lists and print journals located an additional 54 potential studies. Following screening, 280 full-text studies were evaluated which included 88 studies of TMs combined with chemotherapy for CRC, 79 of which employed oxaliplatin regimens. Of these, 39 did not report on CIN, neutropenia or myelosupression, sixreported on mylosuppression or hematologic events only and two reported data that were not suitable for meta-analysis. Finally, 32 studies (2,224 participants) that combined an oxaliplatin regimen with a TM versus the same oxaliplatin regimen and reported outcome data for CIN were included (Fig. 1). Of these, two studies Deng and Shen (2010)[33] and Fang and Li (2008) [34] used G-CSF and two reported neutrophil count as mean difference $[35,36]$, so these studies were analysed separately.

All studies were published from 2005 to 2013. 31 studies were conducted in China and one in Japan [37]. The studies reported all participants were diagnosed as CRC based on pathology tests, and had adequate liver and kidney function and peripheral blood count or no contraindication to chemotherapy pre-study. 26 studies specified life expectancy of three 
months or longer and 17 studies specified no use of chemotherapy for at least one month prior to study commencement (Table 1, TableSupp1, Table Supp 2).

Oxaliplatin regimens included FOLFOX in 30 studies and XELOX in two studies [33,38]. The TMs and chemotherapy were used concurrently. Orally administered TMs were used in 24 studies and 8 studies employed commercially available TM injections. Chinese studies were carried out in the authors' hospital and participants were in-patients. Participant characteristics, interventions, doses and schedules are recorded in Table 1.

\subsection{Methodological assessment}

All studies were described as RCTs. 13 (40.6\%) reported a proper method of random sequence generation and were judged as 'low' risk of bias (Table Supp 3). The other studies did not report the method of sequence generation. No studies reported on how participants were screened. The single study that used external trial management was judged 'low risk' for allocation concealment and blinding of participants and personnel [37]. The other studies did not report on allocation concealment. When there was no identical placebo, studies were judged 'high risk' for blinding of participants or personnel. Details of outcome assessment for CIN were not reported but this is an objective outcome which is measured by laboratory pathologists in a hospital setting so results were unlikely to have been influenced by lack of blinding. Two studies reported the numbers of participants who dropped out during the trial or were lost to follow-up [39,40] but no reasons were given and these missing data were not treated as 'intent to treat', so these were judged as 'high risk' of attrition bias. Studies that had the same numbers of participants at inception as in the outcome reports were judged as 'low risk' of attrition bias. One study had a locatable protocol and was judged as 'low risk' of reporting bias. When there was no protocol the judgement was 'high risk'. The funnel plots for the 32 studies that reported CIN incidence showed asymmetry, so it is likely that were some small studies that did not report CIN data that was non-significant (Figs. Supp 1a \& 1b).

\subsection{Meta-analysis of change in CIN}

All studies used the WHO system or National Cancer Institute Common Toxicity Criteria (NCI-CTC) for grading acute and sub-acute toxicity which divides CIN into 4 grades [41,42]. Data were reported as RR in 30 studies. Meta-analysis was conducted for FN, CIN grade 4, grade 3, grade 3/4, grade 1/2and all grades combined. Data reported as MD for neutrophil counts ( 2 studies) were analysed separately. When RR is less than +1 or MD is less than zero it favors the test group. Only one study reported FN data (see oral administration group).

The overall results showed the test groups significantly reduced CIN compared to control groups for grade 4 , grade 3 , grade $3 / 4$, grade $1 / 2$ and all grades with no statistical heterogeneity $\left(\mathrm{I}^{2}=0 \%\right)$ (Table 2, Fig Supp 2a). Results are also reported for the following subgroups: 1. injection group without G-CSF (7 studies); 2. oral administration group without GCSF (21 studies); 3. studies that used G-CSF (2 studies); and 4. neutrophil count group (2 studies).

\subsubsection{Injection group (no G-CSF)}

Seven studies tested five different injection products, three of which were tested in two studies each (Table 1). There was no difference between groups in the single study that 
reported grade $4 \mathrm{CIN}$ or in the four studies that reported grade 3 . There were significant differences in grade $3 / 4$, grade $1 / 2$, and all grades with no heterogeneity. Incidence rates for grade $3 / 4$ were $4.5 \%$ in the test groups versus $11.1 \%$ in the controls (Table 2, Fig Supp 2a).

\subsubsection{Oral administration group (no G-CSF)}

In 21 studies, TMs were administered orally as decoctions, capsules or tablets. In the four studies that reported grade 4, there was no significant difference between groups. Significant differences were found for grade 3 , grade $3 / 4$, grade $1 / 2$, and all grades with no heterogeneity. Incidence rates for grade $3 / 4$ were $4.6 \%$ in the test groups versus $11.8 \%$ in the controls (Table 2, Fig Supp 2a). The single study that reported FN ( $n=89$ ) [37] found no significant difference between groups.

\subsubsection{G-CSF group}

One study used an injection [34] and one used oral TM [33]. For the pooled data there was no significant difference between groups in grade 3/4andall grades neutropenia. No data were available on FN (Table 2, Fig Supp 2a).

\subsubsection{Neutrophil count}

In the two studies that presented data as mean neutrophil count $[35,36]$ there was a significant difference in favour of the test groups MD $1.62[0.93,2.32] \mathrm{I}^{2}=66 \%$ (Table 2, Fig Supp 2b).

\subsection{Effect of number of cycles of chemotherapy on CIN incidence}

Grade 3/4 CIN incidence was stratified by number of cycles of chemotherapy $(2,3,4,6,8+)$ for the oxaliplatin control groups and the test groups (Table Supp 3). In the control groups, the mean grade 3/4 CIN incidence was higher at 2 cycles (12.30\%) than at 3 cycles $(6.92 \%)$, but then the incidence increased with increasing number cycles to $19.00 \%$ for 8 or more cycles (Fig 2). There were significant reductions in grade 3/4 CIN incidence in the test groups for two cycles RR 0.37 [0.17, 0.80] and four cycles RR 0.26 [0.10, 0.66] with a marginal difference at 6 cycles RR $0.36[0.13,1.02], p=0.05$.There were no significant differences at 3 and 8 cycles or more. It was not feasible to calculate accumulated oxaliplatin and 5-FU dose due to variation in data reporting.

\subsection{Meta-analysis of tumour response rate (tRR)}

To test whether the reduction of CIN was associated with reduction of the cytotoxicity of the chemotherapeutic agents, we pooled results the studies that also reported tRR. Data were available for 6 studies in the injection group, 17 studies in the oral group, one in the G-CSF group and two in the neutrophil count group. The results showed there were no significant reductions in tRR in the pooled data (Table 2, Fig Supp 2c).

\subsection{Effects of individual plant-based ingredients in orally administered TMs}


The multi-ingredient TMs differed in name but their main ingredients were similar. The effects on reduction of CIN of the plant-based ingredients used in multiple studies are reported below at the level of the single plant, pair of plants, and groups of 3 up to 10 plants. It was not feasible to use this procedure for studies of injection products.

All plant-based ingredients $(n=85)$ in the oral TMs were recorded in a spread-sheet. The number of ingredients per intervention averaged 10 and ranged from 1 to 23 . Thirty six plants were used in two or more interventions. The RR (CIN all grades) of the group of studies that included each particular plant was calculated and the RRs were ranked from low to high. The significant RRs were identified ( $\mathrm{n}=36$ ), and groups with moderate or higher heterogeneity (I ${ }^{2}>$ $30 \%)$ were excluded $(n=6)$ leaving 30 different plants in the following analyses. Since the aim was to select plants for further research, only significant RR results that were equal or lower than the total pooled RR of oral interventions $(0.59[0.53,0.67])$ are reported in the text. See Table 3 for all significant RR results. For each of the 30 plants, the full botanical name is given in the first instance together with the Chinese name in pin yin. Thereafter, the name is shortened to the genus only (Table 3).The most frequently used plants were: Atractylodes macrocephala Koidz. (bai zhu) $(\mathrm{n}=15)$; Poria cocos (Schw) Wolf (fu ling) $(\mathrm{n}=13)$; Coix lacryma-jobi L. (yi ren) ( $\mathrm{n}=13)$; Astragalus membranaceus (Fisch.) Bge. (huang qi) $(\mathrm{n}=12)$, and Codonopsis pilosula (Franch.). Nannf. (dang shen) $(\mathrm{n}=10)$.

\subsubsection{Level 1: Single plants}

Of the 30plants included at level 1, six were not always associated with another plant in the TM interventions (Table 3). Of these, Poria $(n=13)$ had the lowest RR $(0.50$ [0.42, 0.60], $\left.\mathrm{I}^{2}=0 \%\right)$ followed by Panax notoginseng (Burk.) F.H. Chen (san qi) $(\mathrm{n}=4)(\mathrm{RR} 0.51[0.36$, $\left.0.72], \mathrm{I}^{2}=0 \%\right)$, Codonopsis $(\mathrm{n}=10)\left(\mathrm{RR} 0.54[0.45,0.65], \mathrm{I}^{2}=0 \%\right)$, Astragalus $(\mathrm{n}=12)(\mathrm{RR} 0.55$ [0.47, 0.65], $\left.\mathrm{I}^{2}=0 \%\right)$, Coix $(\mathrm{n}=13)\left(\mathrm{RR} 0.56[0.48,0.66], \mathrm{I}^{2}=0 \%\right)$, and Atractylodes $(\mathrm{n}=15)$ (RR $\left.0.57[0.50,0.66], \mathrm{I}^{2}=0 \%\right)$. The remaining plants always appeared in association with at least one other plant.

\subsubsection{Level 2: Pairs of plants}

When the 30 plants that showed significant RR results were paired with other plants from level 1, thirteen pairs showed RRs that were lower than the total pool for oral TM interventions (Table 3). The most frequent pairs were Poria + Atractylodes ( $\mathrm{n}=11)(\mathrm{RR} 0.47$ $\left.[0.39,0.57], \mathrm{I}^{2}=0 \%\right)$ and Astragalus + Atractylodes $(\mathrm{n}=11)\left(\mathrm{RR} 0.56[0.48,0.67], \mathrm{I}^{2}=0 \%\right)$. The lowest RRs were for Poria + Coix $(n=9)\left(R R 0.46\right.$ [0.37, 0.57], $\left.I^{2}=0 \%\right)$ followed by Poria + Atractylodes.

\subsubsection{Level 3: Combinations of three plants}

The significant pairs from level 2 were combined with other plants from level 1. Fifteen different triplets showed significant RRs that were lower than the total pool (Table 3). The most frequent combinations were Poria + Atractylodes + Codonopsis $(n=9) R R(0.50[0.40$, $\left.0.62], \mathrm{I}^{2}=0 \%\right)$ and Coix + Atractylodes + Astragalus $(\mathrm{n}=9) \mathrm{RR}\left(0.58[0.48,0.69], \mathrm{I}^{2}=0 \%\right)$. The combination of Poria + Atractylodes + Ligusticum chuanxiong Hort. (chuanxiong) had the lowest RR $\left(0.38[0.22,0.66], \mathrm{I}^{2}=0 \%\right)$ based on two studies. 


\subsubsection{Level 4: Combinations of four plants}

The significant combinations from level 3 were combined into groups of four, using the same method. Thirteen combinations were significant and lower or equal to the pool. Codonopsis + Astragalus + Atractylodes + Poria $(\mathrm{n}=7) \mathrm{RR}\left(0.48[0.38,0.62], \mathrm{I}^{2}=0 \%\right)$ was the most frequent combination. The lowest RR was for Poria + Atractylodes + Coix + Angelica sinensis (Oliv.)(danggui) $(\mathrm{n}=2)\left(\mathrm{RR} 0.38[0.22,0.64], \mathrm{I}^{2}=0 \%\right)$.

\subsubsection{Level 5: Combinations of five plants}

Eight combinations of five plants showed RRs lower than the total pool. The most common combination was Astragalus + Coix + Poria + Codonopsis + Atractylodes ( $\mathrm{n}=6) \mathrm{RR}(0.49$ $\left.[0.37,0.63], \mathrm{I}^{2}=0 \%\right)$. The combination of Astragalus + Atractylodes + Poria + Coix + Smilax glabra $(\mathrm{n}=2)$ had the lowest $\mathrm{RR}\left(0.46[0.27,0.80], \mathrm{I}^{2}=0 \%\right)$.

\subsubsection{Level 6: Combinations of six plants}

Nine combinations of six plants showed significant RRs lower than the total pool. The most common combination $(n=4)$ was Codonopsis + Atractylodes + Astragalus + Coix + Poria + Scutellaria barbata D. Don. (banzhilian) RR $\left(0.50[0.37,0.68], \mathrm{I}^{2}=0 \%\right)$. The combination Codonopsis + Astragalus + Coix + Glycyrrhiza + Atractylodes + Poria $(n=2)$ had the lowest $\operatorname{RR}\left(0.43[0.27,0.68], \mathrm{I}^{2}=0 \%\right)$.

\subsubsection{Level 7: Combinations of seven or more plants}

There was one combination of seven, two combinations of eight and nine, and one combination of ten plants that showed RRs that were significant and lower than the total pool but all combinations were based on two studies only (Table 3 ).

\subsection{TMs with consistent results at multiple levels}

To select plants for further research we identified those that showed reduced RRs at multiple levels. RR results that were significant and lower than the pool total, with heterogeneity less than 30\%,were evident at all eight levels for Atractylodes, Poria, Coix, Astragalus and Codonopsis when used in various combinations. Therefore, when these five plants were included in TM interventions the data suggested a clinical benefit for CIN based on multiple studies. Also, the RRs for the pools of studies that included these plants were lower than the total pool for oral interventions. This was also the most frequent combination of five plants. In the six studies (320 participants) that used this combination, the incidence of all grades CIN was $26.7 \%$ (47/176) compared to 56.4\% (97/172) in the control groups. For 3/4 CIN, this combination showed a significant reduction (RR $0.41[0.17,0.96] \mathrm{I}^{2}=0,5$ studies, 295 participants) with incidences of $4.7 \%$ (7/148) in the test groups and $12.2 \%(18 / 147)$ in the control groups.

\subsection{Potential synergistic effects of TMs}

A number of combinations of plants showed RRs that were lower than those of the plants singly. These included two pairs of plants: Poria + Coix and Poria + Atractylodes; four triplets: Poria + Coix + Atractylodes, Poria + Atractylodes + Astragalus, Poria + Coix + Astragalus, and Poria + Atractylodes + Codonopsis; two groups of four plants: Codonopsis + 
Astragalus + Atractylodes + Poria and Astragalus + Coix + Poria + Codonopsis + Atractylodes; and the group of five mentioned above: Atractylodes + Poria + Coix + Astragalus + Codonopsis (Table 3).

\section{Discussion}

The 32 studies included in the meta-analysis were comparable in that they all employed oxaliplatin regimens in the test and control groups, all participants were diagnosed with CRC, all studies assessed CIN incidence using the WHO criteria, all studies assess performance status and all required no use of chemotherapy in the month prior to commencement. With regard to these aspects, the included studies were similar to other studies of oxaliplatin regimens for CRC. One difference is these studies typically used fewer cycles of chemotherapy (mostly 2 to 4 ) than the large international studies [10,13,43] which may account for the relatively low CIN incidence rates. Number of cycles is an important factor in CIN profile. Sugihara et al 2012 [14] reported 55-88\% CIN (all grades, median of 7-12 cycles) for two Asian studies of FOLFOX 4 for CRC. The 58.9\% (all grades) in the pool of 27 studies (1840 participants) that did not employ prophylaxis with G-CSF was within this range (Table 2). In the case of grade 3/4 CIN, Sugihara et al 2012 reported 37-52\% and Park et al 2015 [44] reported $21.9 \%$ (median 9.7 cycles), both of which were considerably higher than the $11.8 \%$ (88/743) in the control groups of the pooled result for 22 studies (743 participants). A likely reason for this difference is seventeen of the included studies reported CIN at 4 cycles or less of chemotherapy. For studies that employed 8 or more cycles, the CIN incidence for Grade 3/4 (19\%) was close to the result reported by Park et al 2015 (21.9\%).

When the effects of number of cycles of chemotherapy on grade 3/4 CIN incidence was stratified by $2,3,4,6$, and $8+$ cycles, there was a trend towards increased grade $3 / 4 \mathrm{CIN}$ incidence as the number of cycles increased. In Gascon et al 2016, which included various cancers, there was an increase in grade $4 \mathrm{CIN}$ probability with increase in cycles from one (7\%) to six cycles (16\%)[45]. The results of the present analysis support this relationship between CIN incidence and number of chemotherapy cycles. Some other factors that are known to impact in CIN/FN incidence that could not be assessed due to data availability included stage of cancer, treatment history and gender [8].

CIN incidence in the two studies that used G-CSF $[33,34]$ for two cycles was $38 \%$ (all grades) and 3.2\% for grade 3/4 compared to the pool of studies of 2 cycles which reported $63.1 \%$ (all grades) and $12.9 \%$ (grade 3/4). This suggests that the G-CSF was effective in reducing CIN incidence and there were no further reductions with the addition of the TMs

Overall, the addition of the TMs to the oxaliplatin regimens reduced all grades CIN by $24 \%$ (95\% CI 20-28\%) and grade 3/4 CIN by 6\% (95\% CI 3-8\%). Importantly, the addition of the TM interventions did not reduce tumour response rate (Table 2, Fig Supp 2c). This result was consistent with Chen et al 2016 [46]. From the safety perspective, none of the studies reported serious adverse events associated with the addition of the TM intervention to oxaliplatin regimens. Also, the sensitivity analyses based on ingredients did not identify any plants or plant combinations that significantly increased the incidence of CIN in the test groups relative to the controls.

\subsection{Limitations of the study}


The 32 included studies were small in size with an average of 36 participants in the test groups and 33 in the control groups. Although, participants did not use chemotherapy in the month prior to the studies, it is likely that a proportion had been previously treated but separate results were not provided for these sub-groups so was not possible to determine the impact of this factor on CIN incidence.

All studies reported the use of randomization but only $40.6 \%$ reported a valid method for sequence generation and only Kono et al 2013 [37], which was the only study to use external trial management, reported allocation concealment. The issue of how participants were screened for inclusion was not addressed in any of the study reports (Table Supp 3). Therefore there is a risk that selection and randomization were not conducted properly so investigator bias could have affected the results.

Only one study reported blinding of participants. Blinding is difficult to achieve in cancer trials [10] and is especially problematic when oral TM decoctions are used since these have a distinctive smell and taste so it is difficult to construct an identical placebo as control. Consequently, the participants would be well aware they were receiving a TM intervention in addition to other medications. Only Kono et al 2013 [37] provided a protocol, so selective outcome reporting could have been an issue in the other studies. The Funnel plots suggest that non-significant results for CIN were under-reported in small studies and it is likely that this has inflated the benefit identified in the meta-analysis. The paucity of reporting of the details of the trial methodology and consequent high risk of bias in these trials is somewhat mitigated for CIN since this is usually assessed independently by pathologists in Chinese hospitals and included in the patient record. Also, CIN was only one of multiple outcomes of the studies. Nevertheless, bias is an issue in this group of studies so the meta-analysis results should be interpreted with reservation.

\subsection{Effects of the five selected plants in experimental models}

TM interventions are usually composed of multiple ingredients with the intent of enhancing the effectiveness of the treatment and reducing unwanted effects [53]. Although the interventions varied from study to study, the same plants were used in multiple studies. This similarity between interventions was used as the basis for subgroup sensitivity analyses aimed at determining which of the plants may be contributing to reported reductions in CIN incidence. The multi-level analysis procedure provided a systematic approach to pooling the most similar TM interventions and assessing the relative clinical efficacy of different combinations of plants. In the selection of plants for further research, we adopted a conservative approach and only considered plants and groups of plants that consistently appeared at multiple levels in the analysis, as well as demonstrated pooled RRs that were significant, without heterogeneity, and were equal or better than the result for the total pool. Based on these criteria, these plants and groups of plants were considered likely to have contributed to the reduction in neutropenia incidence when combined with oxaliplatin.

When Atractylodes, Poria, Coix, Astragalus and Codonopsis were included in a TM intervention, singly or various combinations, the incidence of CIN in the treatment groups showed greater reductions than found in the pool of 22 studies of oral TMs. Moreover, in the studies that used all five of these plants orally, the incidence of CIN was lower in the test groups (28.0\% all grades; $5.2 \%$ grade $3 / 4)$ than in the controls (58.9\% all grades; $14.3 \%$ grade 
3/4) and there was zero heterogeneity in these pools. Based on these analyses it appears that this group of plants showed the best available clinical evidence for CIN reduction when combined with oxaliplatin regimens (without G-CSF) for CRC. There were insufficient data to assess the effects of any of these plants when combined with G-CSF.

Significant reductions in neutropenia incidence were also found for other plants and plant combinations but the data were insufficient for a consistent pattern of results to be apparent. For example, Panax notoginseng, Ligusticum chuanxiong, Angelica sinensis and Glycyrrhiza uralensis all appeared in subgroups that showed the greatest reductions in CIN incidence at one level. However, these subgroups always included Astragalus, Atractylodes, Codonopsis, Poria and/or Coix. Nevertheless, it is possible that these plants also contributed to the results, so these plants could also be considered for further research. Some have already received research attention. In particular, the combination of Astragalus and Angelica is frequently used for neutropenia in clinical practice and has been the subject of animal studies [54,55]. Also, Astragalus, Atractylodes, Codonopsis, Poria, Angelica and Glycyrrhiza are all commonly used in China for the treatment of myelosuppression induced by chemotherapy for various cancers [56].

To explore the question of how the five main plants might reduce CIN incidence, PubMed and CNKI were searched for experimental studies in models of myelosuppression induced by cytotoxic drugs or irradiation, haematopoiesis, and immune-regulation.

In murine models of myelosuppression induced by cyclophosphamide, intraperitoneal injections of extracts of Astragalus membranaceus injection (AMI) have been reported to promote colony-forming unit-fibroblast (CFU-F) formation that was associated with improved production of interleukin 6 and Granulocyte-macrophage colony-stimulating factor (GM-CSF) by bone marrow stromal cells (BMSC), increasing Bcl-2 protein and mRNA expression in BMSC, thus enhancing survival of BMSC and proliferation of CFU-F [57]. Oral administration of an extract of Astragalus root increased counts of leucocytes and bone marrow $\mathrm{CD} 34^{+}$cells, mean number of CD20 immunopositive $\mathrm{B}$ lymphocytes, and produced significant decreases in the mean area of fat in bone marrow sections [58]. A study of the hematopoietic effect of Astragalus polysaccharides (APS) on healthy human marrow in vitro found that compared to negative control (APS $0 \mathrm{mg} / \mathrm{L}$ ), APS significantly promoted colonyforming unit granulo-monocyte formation at $5 \mathrm{mg} / \mathrm{L}$ with or without presence of GM-CSF, and improved the formation of colony-forming unit erythrocytes with erythropoietin. At 125 $\mathrm{mg} / \mathrm{L}$, APS promoted erythroid burst-forming units only in combination with erythropoietin or phytohemagglutinin [59].

Studies of Shenqifuzheng injection, which is comprised of bioactive components of Astragalus and Codonopsis that mainly contain calycosin-7-O- $\beta$-glucoside, lobetyolin, and astragaloside IV, have reported increases in peripheral white blood cell and bone marrow cell counts, enhanced T cell and B cell proliferation responses, enhanced splenic natural killer cell activity and peritoneal macrophage phagocytosis, and restoration of the level of interleukin-2 in the serum $[60,61]$.

A TM called Liujunzitang which contains Codonopsis, Atractylodes, Poria and Glycyrrhiza, was found to increase counts of white blood cells, reticulocytes and nucleated bone marrow cells in mice with leukopenia induced by cyclophosphamide [62]. In a similar model, the TM 
Shenbaiyin, which mainly is composed of Astragalus and Coix, produced a similar result [63]. In mice administered the microtubule inhibitor epothilone B, the co-administration of the TM Sijunzitang, which contains Atractylodes, Poria and Glycyrrhiza, improved immunity and attenuated myelosuppression [64].

In irradiation induced myelosuppression in mice, Sijunzitang was administered 7 days before irradiation, and continuously for 7 days after the irradiation. The SJZ showed a protective effect on peripheral blood counts of white cells and platelets compared to negative controls [65]. In mice subjected to irradiation, intragastric administration of the saponin astragaloside IV attenuated radiation-induced apoptosis of bone marrow cells, indicating a radio-protective effect [66]. When irradiated mice were injected with an extract of Astragalus root and Angelica sinensis root with weekly assessments for 21 days, the treatment group showed significant recovery of blood cells (platelets, WBC, RBC), and in the colony growth and histology of bone marrow cells harvested after 21 days, compared to the controls [67]. A multi-plant formula that contained Codonopsis was reported to promote the recovery of bone marrow haematopoietic function in a myelosuppression model in irradiated mice [68].

A number of studies have investigated the effects of these five plants on immune response. In healthy chickens, Astragalus polysaccharides (APS)were injected for seven days and the phagocytosis rate and phagocytic index of neutrophil granulocytes in peripheral blood were measured for 56 days. The results showed both measures increased significantly in the APS group, reached the highest level at 28 days, then slowly decreased. At 56 days, the phagocytosis rate and phagocytic index were still higher than the negative control for APS doses of $12.5 \mathrm{mg} / \mathrm{ml}, 25 \mathrm{mg} / \mathrm{ml}$ and $50 \mathrm{mg} / \mathrm{ml}$. [69]. A study of the effects of an aqueous extract of APS reported the extract stimulated activity of RAW264.7 macrophages [70]. A polysaccharide derived from Codonopsis was reported to reduce tumor growth and activate the immune system in mice inoculated with Hepatoma-22 (H22) cells [71]. Codonopsis polysaccharides have also been reported to improve immunity in mice with immunosuppression induced by cyclophosphamide [72,73]. Polysaccharides from Atractylodes exhibited immune-enhancing activity in-vitro in a study of splenic T-lymphocyte proliferation [74]. A glycoprotein purified from Poria was reported to activate RAW 264.7 macrophages in-vitro[75] and a review of the pharmacological properties of Poria found that its polysaccharides appear to potentiate immune response by up-regulating immune stimulators and down-regulating immune suppressors [76].

Coix has been developed into an anti-tumor drug in China called Kanglaite injection which can be combined with chemotherapy. Besides its inhibitory effects on tumor growth, it has been reported to stimulate $\mathrm{T}$ cell proliferation in C57BL/6 mice with Lewis lung carcinoma [77], rescue the levels of CD4+ T cells in tumor bearing mice, and increase the number of $\mathrm{T}$ cells and natural killer cells in the blood of hepatocellular carcinoma patients [78].

Although there have been studies of these five plants or their constituents in experimental models, this does not mean that these plants acted via the same mechanisms in the clinical studies. Also, it cannot be inferred that the plants for which there was more experimental evidence were more effective than other short-listed plants. These issues require further research. It should be noted that the sensitivity analysis procedure used for the selection of the above five plants did not allow any tests between the groups of TMs included in Table 3, so 
relative ranking is not an index of clinical effectiveness. The purpose of the ranking was shortlisting candidates for further research from amongst a large list of potentially interesting TMs.

\subsection{Is there any evidence for synergetic effects?}

The plant combinations identified as potentially having synergistic effects in the above sensitivity analyses were various combinations of Codonopsis, Atractylodes, Poria, Astragalus and Coix. Of these, Codonopsis, Atractylodes and Poria are the main components of the multi-component TM Sijunzitang [79]. Sijunzitang and its modifications, which frequently include addition of Astragalus, have been used clinically as adjuncts to chemotherapy for various cancers in China [80-82]. We could not locate any studies that investigated potential synergistic effects of the components of Sijunzitang in models of neutropenia but there have been reports in other models. In AHH-1 human lymphoblasts, the addition of aqueous extracts of Sijunzitang improved survival and growth following irradiation, with an effect that was greater than for extracts of any of the four component plants used singly [65]. A study of normal rat small intestine epithelial IEC-6 cells, which aimed to investigate the effects of the individual ingredients of Sijunzitang plus Astragalus on promoting healing of small intestine epithelial IEC- 6 cells, reported that the combination of Codonopsis plus Atractylodes and the combination of Atractylodes plus Astragalus, showed enhanced effects when compared to these TMs used singly [83].

A study of rat bone marrow stem cells investigated the effects of extracts of Astragalus and Angelica sinensis, singly and in combination, on proliferation and vascular endothelial growth factor (VEGF) expression. It reported that the Astragalus promoted stem cell proliferation and induced protein expression of VEGF while there was no significant effect for the Angelica extract, however, the combination of Astragalus plus Angelica was better than Astragalus extract alone [84]. In a study of TMs used for neutropenia in cancer treatment in China, Astragalus and Angelica were the two most frequent [56]. However, the frequency of Angelica was relatively low in the included studies so it was not possible to determine whether it was consistently associated with reductions in CIN incidence.

Overall, the evidence for potential synergistic effects of these TM combinations is scanty and the effects on neutropenia have received relatively little research attention. However, an invivo study of a different combination of four TMs found marked differences in tumour response, body weight and/or mortality in a CRC model when certain TMs were omitted from the formulation [103]. Future studies could consider a similar approach to investigating the effects of specific TM combinations in CIN models.

\section{Conclusions}

These meta-analyses suggest that the addition of certain TMs to oxaliplatin regimens was associated with reduced CIN incidence. However, there was considerable risk that bias in the conduct of the studies could have influenced results so strong conclusions could not be drawn. Future clinical studies require adequate protocols, sufficient durations and sample sizes, and should report results for each grade of CIN and for neutrophil counts.

Of the plants used in the clinical studies, Astragalus, Codonopsis, Atractylodes, Poria and Coix in various combinations were associated with reduced neutropenia incidence in multiple 
studies when administered orally. In experimental studies, each of these plants has been reported to reduce myelosuppression and/or enhance immune response. However, these experimental studies employed a diversity of cell-lines and animal models, the test materials ranged from whole plant extracts to isolated compounds, and there was little evidence of replication. Future studies could investigate the effects of fractionated extracts of these TMs, singly and in combination to systematically assess their effects on neutrophil counts in animal models of chemotherapy and in models with intact bone marrow and immunity. This may lead to the development of interventions to supplement the conventional treatment of CRC.

\section{Acknowledgements}

(deleted)

\section{Funding support}

(deleted)

\section{Conflict of interest statement}

\section{MS CROH-D-15-00208R1}

The authors have received no honoraria and have no financial interests or other conflicts of interest related to the material in this manuscript.

\section{Authors' contributions}

MC, BM, IZ conducted searches, extracted and analyzed data. CX, AX, BM and MC were involved in the conceptualization of the study. $\mathrm{MC}$ and $\mathrm{BM}$ drafted the original version of the manuscript. AZ, CX, DT and IZ provided critical comment and participated in manuscript revisions. All authors approved the final version.

\section{Funding support}

1. The project is partially supported by an International Research Grant from the Guangdong Provincial Academy of Chinese Medical Sciences, Guangdong Province, China.

2. Menghua Chen is supported by an Australian Postgraduate Award at RMIT University, Australia.

\section{Authors' contributions}

$\mathrm{MC}, \mathrm{BM}, \mathrm{IZ}$ conducted searches, extracted and analyzed data. CX, AX, BM and MC were involved in the conceptualization of the study. $\mathrm{MC}$ and $\mathrm{BM}$ drafted the original version of the manuscript. AZ, CX, DT and IZ provided critical comment and participated in manuscript revisions. All authors approved the final version.

\section{Acknowledgements}

We wish to thank Dr Johannah Shergis for conducting Egger's test. 


\section{References}

[1] Ferlay J, Soerjomataram I, Dikshit R, et al. Cancer incidence and mortality worldwide: Sources, methods and major patterns in GLOBOCAN 2012. Int J Cancer. 2015; 136:E359386. DOI:10.1002/ijc.29210.

[2] Raymond E, Faivre S, Woynarowski JM, Chaney SG. Oxaliplatin: mechanism of action and antineoplastic activity. Semin in Oncol. 1998; 25:4-12.

[3] Gustavsson B, Carlsson G, Machover D, et al. A review of the evolution of systemic chemotherapy in the management of colorectal cancer. Clin Colorectal Cancer. 2015; 14:110.DOI: 10.1016/j.clcc.2014.11.002.

[4] Hirsch BR, Zafar SY. Capecitabine in the management of colorectal cancer. Cancer Manag Res.2011; 3:79-89. DOI: 10.2147/cmr.s11250.

[5] Dale DC. Colony-stimulating factors for the management of neutropenia in cancer patients. Drugs. 2002; 62 Suppl 1:1-15.

[6] Crawford J, Dale DC, Lyman GH. Chemotherapy-induced neutropenia: risks, consequences, and new directions for its management. Cancer. 2004; 100:228-237. DOI: 10.1002/cncr.11882.

[7] Koini F, Nintos G, Georgoulias V, et al. Therapeutic strategies for chemotherapy-induced neutropenia in patients with solid tumors. Expert Opinion on Pharmacotherapy. 2015; 16:1505-1519. DOI: org/10.1517/14656566.2015.1055248.

[8] Aapro M, Crawford J, Kamioner D. Prophylaxis of chemotherapy-induced febrile neutropenia with granulocyte colony-stimulating factors: where are we now? Support Care Cancer. 2010; 18:529-541. DOI: 10.1007/s00520-010-0816-y.

[9] Lyman GH, Lyman CH, Agboola O. Risk models for predicting chemotherapy-induced neutropenia. The oncologist. 2005; 10: 427-437. DOI: 10.1634/theoncologist.10-6-427.

[10] Hind D, Tappenden P, Tumur I, et al. The use of irinotecan, oxaliplatin and raltitrexed for the treatment of advanced colorectal cancer: systematic review and economic evaluation. Health Technol Assess. 2008; 12:3-9, 11-162.

[11] Sugihara K, Ohtsu A, Shimada Y, et al. Safety analysis of FOLFOX4 treatment in colorectal cancer patients: a comparison between two Asian studies and four western studies. Clin Colorectal Cancer. 2012; 11:127-137. DOI: 10.1016/j.clcc.2011.09.001.

[12] Becouarn Y, Ychou M, Ducreux M, et al. Phase II trial of oxaliplatin as first-line chemotherapy in metastatic colorectal cancer patients. Digestive Group of French Federation of Cancer Centers. J Clin Oncol. 1998; 16:2739-2744. 
[13] de Gramont A, Figer A, Seymour M, et al. Leucovorin and fluorouracil with or without oxaliplatin as first-line treatment in advanced colorectal cancer. J Clin Oncol. 2000; 18:29382947.

[14] Boisdron-Celle M, Craipeau MC, Brienza S, et al. Influence of oxaliplatin on 5fluorouracil plasma clearance and clinical consequences. Cancer Chem Pharm. 2002; 49:235243. DOI: 10.1007/s00280-001-0406-2.[15] Saarinen UM, Hovi L, Riikonen P, et al. Recombinant human granulocyte-macrophage colony-stimulating factor in children with chemotherapy-induced neutropenia. Med Pediatr Oncol. 1992; 20:489-96.

[16] Lydaki E, Bolonaki E, Stiakaki E, Dimitriou H, Kalmantis T, Kalmanti M. Efficacy of recombinant human granulocyte colony-stimulating factor and recombinant human granulocyte macrophage colony-stimulating factor in neutropenic children with malignancies. Pediatr Hematol Oncol. 1995; 12:551-558.

[17] Gomez Raposo C, Pinto Marin A, Gonzalez Baron M. Colony-stimulating factors: clinical evidence for treatment and prophylaxis of chemotherapy-induced febrile neutropenia. Clin Transl Oncol. 2006; 8:729-734.

[18] Hecht JR, Pillai M, Gollard R, et al. A randomized, placebo-controlled phase II study evaluating the reduction of neutropenia and febrile neutropenia in patients with colorectal cancer receiving pegfilgrastim with every-2-week chemotherapy. Clin Colorectal Cancer. 2010; 9:95-101. DOI: 10.3816/CCC.2010.n.013.

[19] Hendler D, Rizel S, Yerushalmi R, et al. Different schedules of granulocyte growth factor support for patients with breast cancer receiving adjuvant dose-dense chemotherapy: a prospective nonrandomized study. Am J Clin Oncol. 2011; 34:619-624. DOI: 10.1097/COC.0b013e3181f94716.

[20] Gascón P, Tesch H, Verpoort K, et al. Clinical experience with Zarzio® in Europe: what have we learned? Support Care Cancer. 2013; 21:2925-2932. DOI: 10.1007/s00520-0131911-7 2013

[21] Saif M, Lansigan F, Ruta S, et al. Phase I study of the botanical formulation PHY906 with capecitabine in advanced pancreatic and other gastrointestinal malignancies.

Phytomedicine. 2010; 17:161-169. DOI: 10.1016/j.phymed.2009.12.016.

[22] Chen S, Flower A, Ritchie A, et al. Oral Chinese herbal medicine (CHM) as an adjuvant treatment during chemotherapy for non-small cell lung cancer: A systematic review. Lung Cancer. 2009; 68:137-145. DOI: 10.1016/j.lungcan.2009.11.008.

[23] Chen MH, May BH, Zhou IW, et al. Integrative medicine for relief of nausea and vomiting in the treatment of colorectal cancer using oxaliplatin-based chemotherapy: A systematic review and meta-analysis. Phytother Res. 2016; Feb 23 [Epub ahead of print]. DOI: 10.1002/ptr.5586.

[24] McCulloch M, See C, Shu XJ, et al. Astragalus-based Chinese herbs and platinum-based chemotherapy for advanced non-small-cell lung cancer: meta-analysis of randomized trials. J Clin Oncol. 2006; 24:419-430. DOI: 10.1200/JCO.2005.03.6392 
[25] Chen M, May BH, Zhou IW, Xue CC, Zhang AL. FOLFOX 4 combined with herbal medicine for advanced colorectal cancer: a systematic review. Phytother Res. 2014; 28:976991. DOI: $10.1002 /$ ptr.5092.

[26] Gong T. Progress in Chinese medicine treatment of leucopenia after chemotherapy. [in Chinese]. Guiding J of Traditional Chinese Medicine and Pharmacy. 2010; 16:105-106.

[27] Shergis JL, Zhang AL, Zhou WY, Xue CC. Panax ginseng in randomised controlled trials: a systematic review. Phytother Res. 2013; 27:949-965. DOI: 10.1002/ptr.4832.

[28] Yang S, Wang LM, Wang SQ, Guo XL, Ren DM. Job's tears components and bioactivity. [in Chinese]. J Chinese Medicinal Materials. 2011; 34:1306-1312.

[29] Fu J, Wang Z, Huang L, et al. Review of the botanical characteristics, phytochemistry, and pharmacology of Astragalus membranaceus (huangqi). Phytother Res. 2014; 28:12751283. DOI: $10.1002 /$ ptr.5188.

[30] Moher D, Liberati A, Tetzlaff J, et al. The PRISMA Group. Preferred Reporting Items for Systematic Reviews and Meta-Analyses: The PRISMA Statement. 2009; PLoS Med 6: e1000097. DOI:10.1371/journal.pmed1000097.

[31] Friedrich JO, Adhikari NK, Beyene J. Inclusion of zero total event trials in meta-analyses maintains analytic consistency and incorporates all available data. BMC Med Res Methodol. 2007; 7:1-6. DOI: 10.1186/1471-2288-7-5.

[32] Higgins JPT, Green S, (editors). Cochrane Handbook for Systematic Reviews of Interventions Version 5.1.0. The Cochrane Collaboration. 2011: www.cochrane-handbook.org.

[33] Deng D, Shen X. Clinical observation of Yiqixiaoji decoction combined with chemotherapy treatment on 18 cases of advanced colorectal cancer. [in Chinese]. Fujian $\mathrm{J}$ Traditional Chinese Medicine. 2010; 41:13-14.

[34] Fang MZ, Li M. The curative effect of the treatment for metastatic colorectal cancer by the FOLFOX4 scheme combining Javanica oil emulsion and the observation of adverse effects. [in Chinese]. Chinese J Information on Traditional Chinese Medicine. 2008; 15:74-75.

[35] Xu YX, Wang SL. Clinical observation of Jiangniling combined with chemotherapy treatment on advanced colorectal cancer. [in Chinese].China Medical Herald. 2010; 7: 84-85.

[36] Zeng C, Deng XM, Du JY,et al. Clinical observation of combined traditional Chinese and western medicine treatment of 61 patients with advanced colon cancer. [in Chinese]. Chinese J Experimental Traditional Medical Formulae. 2013; 8: 335-37.

[37] Kono T, Hata T, Morita S, et al. Goshajinkigan oxaliplatin neurotoxicity evaluation (GONE): a phase 2, multicenter, randomized, double blind, placebo controlled trial of goshajinkigan to prevent oxaliplatin induced neuropathy. Cancer Chemotherapy and Pharmacology. 2013; 72:1283-1290.DOI: 10.1007/s00280-013-2306-7.

[38] Wang YT. Xiaoaipin combined with XELOX on treatment of advanced colorectal cancer [in Chinese]. Northern Pharmacy. 2013; 10:55. 
[39] Li YJ, Chen JZ, Huang WX, Li XF. Treatment of Wenshen Jianpi Fang combination with chemotherapy for advanced colorectal cancer. [in Chinese]. Fujian J Traditional Chinese Medicine. 2007; 38:13-14.

[40] Zhang Q, Wang X, Yang G. Clinical research of Guben Xiaoliu Capsule combined with FOLFOX4 plan for treatment of advanced colorectal cancer. [in Chinese]. Beijing J of TCM. 2010; 14:255-257.

[41] Miller AB, Hoogstraten B, Staquet M, Winkler A. Reporting results of cancer treatment. Cancer. 1981; 47:207-214.

[42] National Cancer Institute. Common Toxicity Criteria. Version 2.0. National Cancer Institute; 1999.

[43] Cassidy J, Clarke S,Diaz-Rubio E, et al. Randomized phase III study of capecitabine plus oxaliplatin compared with fluorouracil/folinic acid plus oxaliplatin as first-line therapy for metastatic colorectal cancer. J Clin Oncol. 2008; 26: 2006-12. DOI:

$10.1200 /$ jco.2007.14.9898

[44] Park YS, Ji JF, Zalcberg JR, et al. Oxaliplatin/5-fluorouracil-based adjuvant chemotherapy as a standard of care for colon cancer in clinical practice: Outcomes of the ACCElox registry. Asia-Pacific Journal of Clinical Oncology. 2015; 11: 334-342. DOI: 10.1111/ajco.12409.

[45] Gascón P, Aapro M, Ludwig H, et al. Treatment patterns and outcomes in the prophylaxis of chemotherapy-induced (febrile) neutropenia with biosimilar filgrastim (the MONITOR-GCSF study). Support Care Cancer. 2016; 24:911-925. DOI: 10.1007/s00520015-2861-z.

[46] Chen MH, May BH, Zhu IW, et al. Meta-analysis of oxaliplatin-based chemotherapy combined with traditional medicines for colorectal cancer: contributions of specific plants to tumor response. Integr Cancer Ther. 2016; 15:40-59. DOI: 10.1177/1534735415596424

[47] Ding X, Xiao XY, Yang XY, et al. Clinical observation of compound Kushen injection combined with FOLFOX4 regime for patients with advanced colorectal cancer. [in Chinese]. China Oncology. 2010; 20:860-863.

[48] Tao CL, Xu JF. Co-Kushen injection combined with chemotherapy on treatment of advanced colorectal cancer. [in Chinese]. Guiding J of Traditional Chinese Medicine and Pharmacy. 2013; 19:42-44.

[49] Li H, Dong L, Fu S, et al. Comparative study on treatment of advanced colorectal cancer by Aidi injection combined with FOLFOX4 regimen and by FOLFOX4 regimen alone. [in Chinese]. Chinese J of Integrated Traditional and Western Medicine. 2007; 27:1086-1089.

[50] Wang YT, Peng L. Clinical study on Aidi injection combined with FOLFOX4 regimen in the treatment of advanced colorectal cancer. [in Chinese]. Qingdao Med J. 2012; 44:173174.doi:10.2969/j.issn.1006-557 
[51] Qiu ZC. Kang'ai Injection combined with chemotherapy in treating advanced colorectal cancer. [in Chinese]. Shaanxi J Traditional Chinese Medicine. 2011; 32:3-4.

[52] Yang YF. The comparative study of Kang'ai injection combined with FOLFOX4 regimen for advanced colorectal cancer. [thesis in Chinese]. Fuzhou, Fujian University of Traditional Chinese Medicine. 2008.

[53] Jia W, Gao WY, Yan YQ, et al. The rediscovery of ancient Chinese herbal formulas. Phytother Res. 2004; 18:681-686. DOI: 10.1002/ptr.1506.

[54] Yang L, Zhang LH, Yi Z. Influence of Danggui buxue tang on the proliferation of bone marrow cells of mice. [in Chinese]. J Clinical Rehabilitative Tissue Engineering Research. 2007; 3:538- 539 .

[55] Yan SC, Zhu BD, Han YG, et al. Effect of different Danggui Buxue Tang combination and compatibility on myelosuppression in mice. [in Chinese]. Chin Pharm J. 2008; 43:13861390.

[56] Wang M, Jin J, Zhang LP, et al. Study of medication principle about Chinese medicine in treatment of bone marrow suppression after chemotherapy. [in Chinese]. J Liaoning University of TCM. 2014; 16:147-149.

[57] Zhu XL, Zhu BD. Mechanisms by which Astragalus membranaceus injection regulates hematopoiesis in myelosuppressed mice. Phytother Res. 2007; 21:663-667. DOI: 10.1002/ptr.2144.

[58] Ismail ZM, Amin NM, Yacoub MF, et al. Myelo-enhancement by astragalus membranaceus in male albino rats with chemotherapy myelo-suppression.histological and immunohistochemical study. Int J Stem Cells. 2014; 7:12-22. DOI: 10.15283/ijsc.2014.7.1.12.

[59] Zhang ZP, Hong JM. Study of Astragalus polysaccharides on the proliferation of human hematopoietic progenitor cells in vitro. [in Chinese]. Pharmacology and Clinics of Chinese Materia Medica. 2000; 16:16-17. DOI :10.13412/j .cnki .zyy 1.2000.01.009.

[60] Wang J, Tong X, Li P, et al. Immuno-enhancement effects of Shenqi Fuzheng injection on cyclophosphamide-induced immunosuppression in Balb/c mice. J Ethnopharmacol. 2012; 139:788-795. DOI: 10.1016/j.jep.2011.12.019.

[61] Wang J, Tong X, Li P, et al. Bioactive components on immuno-enhancement effects in the traditional Chinese medicine Shenqi Fuzheng Injection based on relevance analysis between chemical HPLC fingerprints and in vivo biological effects. J Ethnopharmacol. 2014; 155:405-415.DOI: 10.1016/j.jep.2014.05.038.

[62] Yuan XH. Effects of traditional LiuJunZi decoction on immunity and hematopoietic function of leukopenia animal model in mice. [in Chinese]. China Medical Herald. 2008; 5:65-66.

[63] Li YS, Jiang JL, Li T, et al. Effects of traditional Sheng Bai Yin on immune and hematopoietic function of leukopenia animal model in mice. [in Chinese]. J Hubei Institute for Nationalities (Medical Edition). 2006; 23:7-10. 
[64] Zhang HY. Si Jun Zi Tang extracts mitigate epothilone B chemotherapeutic toxicity and composition analysis [thesis in Chinese]. University of Zhongnan. 2014.

[65] Li C, Shao S, Tu XM, et al. Effects of Si Jun Zi decoction on body weight and peripheral blood in ${ }^{60} \mathrm{Co} \Upsilon$ irradiated mice. [in Chinese]. Radiation Protection. 2015; 35:345-350.

[66] Li YR, Cao W, Guo J, et al. Comparative investigations on the protective effects of Rhodioside, Ciwujianoside-B and Astragaloside IV on radiation injuries of the hematopoietic system in mice. Phytother Res. 2011; 25:644-653. DOI: 10.1002/ptr.3313.

[67] Yang M, Chan GC, Deng R, et al. An herbal decoction of Radix Astragali and Radix Angelicae Sinensis promotes hematopoiesis and thrombopoiesis. J Ethnopharmacol. 2009; 124:87-97. DOI: 10.1016/j.jep. 2009.04.007.

[68] Liu M, Tan H, Zhang X, et al. Hematopoietic effects and mechanisms of Fufang Ejiao Jiang on radiotherapy and chemotherapy-induced myelosuppressed mice. J Ethnopharmacol. 2014; 152:575-584. DOI: 10.1016/j.jep.2014.02.012.

[69] Li XY, Jin LY. Effects of polysaccharide extracted from traditional Chinese medical herbs on the phagocytosis of neutrophil granulocyte in peripheral blood of chickens. Journal of Traditional Chinese Veterinary Medicine. 2014; 1:56-59. DOI:10.13823/j.cnki.jtcvm. 2014.01.013

[70] Zhao LH, Ma ZX, Zhu J, et al. Characterization of polysaccharide from Astragalus Radix as the macrophage stimulator. Cell Immunol. 2011; 271:329-334. DOI: 10.1016/j.cellimm. 2011.07.011.

[71] Xu C, Liu Y, Yuan G, et al. The contribution of side chains to antitumor activity of a polysaccharide from Codonopsis pilosula. Int J Biol Macromol. 2012; 50:891-894. DOI: 10.1016/j.ijbiomac. 2012.01.013.

[72] Zhang XJ, Zhu CC, Hu L, et al. Pharmacological action of polysaccharides from Radix Codonopsis on immune function and hematopoiesis in mice. [in Chinese]. Traditional Chinese Drug Research and Clinical Pharmacology. 2003, 14:174-176.

[73] Gong QH, Zhao W, Yu L, et al. Comparison of polysaccharides from Radix Codonopsis in two different places of production on immune function in mice. [in Chinese]. ACTA Academiae Medicinae Zunyi. 2012; 35:267-270.

[74] Sun W, Meng K, Qi C, et al. Immune-enhancing activity of polysaccharides isolated from Atractylodis macrocephalae Koidz. Carbohydr Polym. 2015; 126:91-96. DOI: 10.1016/j.carbpol. 2015.03.034.

[75] Chang HH, Yeh CH, Sheu F. A novel immunomodulatory protein from Poria cocos induces Tolllike receptor 4-dependent activation within mouse peritoneal macrophages. J. Agric Food Chem. 2009; 57:6129-6139. DOI: 10.1021/jf9011399.

[76] Rios JL. Chemical constituents and pharmacological properties of Poria cocos. Planta Med. 2011; 77:681-91. DOI: 10.1055/s-0030-1270823. 
[77] Pan P, Wu Y, Guo ZY et al. Antitumor activity and immunomodulatory effects of the intraperitoneal administration of Kanglaite in vivo in Lewis lung carcinoma. $\mathbf{J}$

Ethnopharmacol. 2012; 143:680-5. DOI: 10.1016/j.jep.2012.07.025.

[78] Huang X, Qin J, Lu S. Kanglaite stimulates anticancer immune responses and inhibits HepG2 cell transplantation induced tumor growth. Mol Med Rep. 2014; 10:2153-2159. DOI: $10.3892 / \mathrm{mmr} .2014 .2479$.

[79] Duan SH, Peng B, Yang RX. Analysis of application of prescription Sijunzitang. [in Chinese]. J Practical Traditional Chinese Internal Medicine. 2011; 25:84-85.

[80] Huang ZH. Sijunzitang combined conventional radiotherapy for esophageal cancer randomized parallel group study. [in Chinese]. J Practical Traditional Chinese Internal Medicine. 2014; 28:74-76.

[81] Zhang D, Chen Q, Mo JP. Sijunzitang combined treatment of lung cancer chemotherapy Azasetron gastrointestinal reactions: randomized controlled study. [in Chinese]. J Practical Traditional Chinese Internal Medicine. 2013; 27:121-123.

[82] Gan YL, Jiao D, Liu WF. Treatment of gastrointestinal cancer multi-drug resistance gene-positive cases by Sijunzitang with chemotherapy. [in Chinese]. Chinese J Experimental Traditional Medical Formulae. 2010; 16:253-255.

[83] Zhang ZL, Chen WW. The influence of the combination of codonopsis, astragalus, and atractylodes on the proliferation of small intestine epithelial IEC-6 cells. [in Chinese]. J Guangzhou University of Traditional Chinese Medicine. 2002; 19:137-140.

[84] Shen B, Chen L, Zhou K, Jin KK. Effects of astragalus and angelica on bone marrow stem cells proliferation and VEGF protein expression in vitro. [in Chinese]. China J Orthop Trauma. 2011; 24:652-655.

[85] Hu A, Chuan Y, Li Z. The Clinical efficacy of chemotherapy combined with Chinese traditional drugs for advanced colorectal cancer patients. [in Chinese]. The Practical J Cancer. 2006; 21:74-76.

[86] Lao GQ, Chen F, He XH, et al. Clinical research on treating advanced colorectal cancer with the Jianpi Jiedu decoction plus chemotherapy. [in Chinese]. Clinical J Chinese Medicine. 2012; 4:1- 3 .

[87] Lim MH, Zhu DZ. Pien Tze Huang combined with chemotherapy on treatment of advanced colon cancer. [in Chinese]. Fujian J Traditional Chinese Medicine. 2012; 43:8-9.

[88] Liu H, Sun MF. Clinical observation of kang'ai fangyi tablet combined with chemotherapy in treating advanced colorectal cancer. [in Chinese]. Chinese J Information on Traditional Chinese Medicine. 2009; 16:2.

[89] Liu J, Wang W, Zhou Y. Observation on therapeutic effect of Jianpi Huoxue herbs combined with chemotherapy in treating post-operational colonic cancer patients. [in Chinese]. Chinese J Integr Med. 2005; 25:207-209. 
[90] Liu WY, Liu QY, Liu HW et al. Clinical study of combination of Chinese traditional and Western medicine for 16 advanced colorectal cancer. [in Chinese]. Jilin J Traditional Chinese Medicine. 2011; 31:984-985.

[91] Ma J, Wang G, Cai D, Fan Y, Gu X. Clinical observation of Jianpi Xiaoliu decoction in preventing post-operative colorectal carcinoma recurrence and metastasis. [in Chinese]. Shanghai J TCM. 2005; 39:24-25.

[92] Song WX, Zhang WW. Clinical study of combination of Xiaoliuhuaji Decoction II and chemotherapy on the treatment of advanced colorectal cancer. [in Chinese]. Jiangxi J of TCM. 2012; 44:13-14.

[93] Wang $\mathrm{H}$. The observation on efficacy of Yiqi Huoxue Buchang decoction with chemotherapy in patients with rectal cancer of post-operation. [in Chinese]. J of Liaoning University of TCM. 2008; 10:81-82.

[94] Wang JZ, Ke YH, Liu PC, Wu CY, Chen HB. Yichangning decoction combined with FOLFOX4 on treatment of advanced colorectal cancer. [in Chinese]. Fujian J TCM. 2011; 42:23-24.

[95] Wu G, Yu G, Li J, Xiong F. Short term therapeutic effect on treatment of postoperational large intestine carcinoma by Fupiyiwei decoction combined with chemotherapy and it's effect on immune function. [in Chinese]. China J Chinese Materia Medica. 2010; 35:782-785.

[96] Yang CB, Yuan J, Zhu L. Clinical study on jianpikangfu pills for treatment of 50 cases of advanced colorectal cancer. [in Chinese]. J Emerg TCM. 2007; 16:1198-1199.

[97] Zeng J, Li Z, Wang X. Traditional Chinese medicine with chemotherapy treatment on advanced colorectal carcinoma: reported of 30 cases. [in Chinese]. J Jiangxi University of Traditional Chinese Medicine. 2008; 20:39-41.

[98] Zhang Q, Zhao W, Yu J, Wang X. Clinical study on advanced colorectal cancer treated by Yiqi Huoxue TCM combined with chemotherapy. [in Chinese]. Chinese J Information on TCM. 2006; 13:17-18.

[99] Zhang WW, Song WX. Clinical study of combination of Xiaoliuhuaji decoction I and chemotherapy on the treatment of post-operative colorectal cancer. [in Chinese]. Hebei J TCM. 2013; 35:69-71.

[100] Zhang Y, Xu J, Sun J. Clinical study of Jianpi Jiedu decoction plus FOLFOX4 regimen in the treatment of advanced colorectal cancer. [in Chinese]. Global Traditional Chinese Medicine. 2010; 3:117-120.

[101] Zhou J. Observation of clinical efficacy of Fuzheng Jianpi decoction combined with chemotherapy in treatment of advanced colorectal cancer. [in Chinese]. Chinese Archives of TCM. 2011; 29:2814-2816. 
[102] Zeng DX, Ling Y, Yang QL, Sun Y. Ginsenoside Rg3 capsules combined with FOLFOX4 regimen for treatment of advanced colon cancer: a report of 35 cases. [in Chinese]. J Bengbu Medical College 2009; 34: 1092-94.

[103] Liu SH, Chang YC. Old formula, new Rx: The journey of PHY906 as cancer adjuvant therapy. J Ethnopham. 2012; 140: 614-623. DOI:10.1016/j.jep.2012.01.047. 


\section{Biographies}

Menghua Chen graduated with a Bachelor of Medicine (BMed) from Guangzhou University of TCM, China in 1985. He worked as a physician in the Guangdong Hospital of TCM until 1990. Since 1991 he has been in private practice in Melbourne, Australia and is currently a doctoral candidate at RMIT University where he is undertaking clinical and experimental research into natural products for colorectal cancer.

Brian H May received a Master of Letters from University of New England, Australia in 1997 and a PhD from RMIT University in 2010. He is currently a research fellow at RMIT University and has authored over 40 peer reviewed articles in the fields of natural products, clinical trials, systematic reviews and meta-analysis.

Iris Wenyu Zhou received a PhD from RMIT University, Australia in 2008. She has worked as a research fellow at RMIT University for 6 years. Her current research expertise and interests include health workforce, educational research, population surveys on the utilisation of complementary and alternative medicine, questionnaire and survey design, critical appraisal of clinical evidence, systematic reviews and meta-analysis.

Daniel Man-yuen Sze obtained his PhD in Immunology (University of Birmingham UK) and a second PhD in Higher Education (University of Sydney Australia). As a cancer Immunologist, Daniel was awarded an Australian NSW Cancer Institute Career Development Fellowship and established the 'Cancer Immunology Group' at the Faculty of Pharmacy of the University of Sydney. He led the cancer research theme under the National Institute of Complementary Medicine (Australia) NICM Collaborative Centre of Traditional Chinese Medicine and is Secretary General of the Advisory Committee of the Consortium for Globalisation of Chinese Medicine.

Charlie C Xue is Head of School, School of Health Sciences, RMIT University. He graduated from Guangzhou University of Chinese Medicine, China in 1987 as Graduate of the Year and received a PhD from RMIT University in 2000. He is a member of the World Health Organization (WHO) Expert Advisory Panel for Traditional Medicine; Director of the World Health Organization (WHO) Collaborating Centre for Traditional Medicine; and Chair of the national regulatory authority the Chinese Medicine Board of Australia. He has been a principal investigator on more than 20 research projects including project grants from the National Health and Medical Research Council (NHMRC), Australian Research Council (ARC) and other projects funded by industry and government. These and other research endeavors have resulted in over 200 publications and $25 \mathrm{PhD}$ graduates.

Tony Zhang is Head of Discipline of Chinese Medicine at the School of Health Sciences, RMIT University, Australia and Deputy Director of China-Australia International Research Centre for Chinese Medicine. He has a Bachelor of Medicine (Chinese Medicine) from China, a Master of Public Health from the University of New South Wales and PhD from RMIT University. His research expertise is in systematic review/meta-analysis and the management of multi-centre clinical trials. He has published more than 60 peer-reviewed journal articles, book chapters and research reports. He is internationally active in contributing to professional activities including: External Reviewer for Australian National Health and Medical Research Council Project Grant and Hong Kong Health and Medical Research Fund; Editorial Board Member of 10 scientific journals including American Journal of Chinese Medicine and BMC 
Complementary and Alternative Medicine. He has been a reviewer for 25 scientific journals including Cochrane Database Systematic Review; PLOS One; British Journal of Cancer; American Journal of Public Health; Pharmacoepidemiology \& Drug Safety and Phytotherapy Research. 


\section{Figure captions}

Fig. 1. Flow diagram of the search and selection process of RCTs of oxaliplatin regimens combined with traditional medicine (TM) for colorectal cancer (CRC) with chemotherapy induced neutropenia (CIN) as an outcome

Legend

CT: clinical trial of TM without randomisation; DU: duplicate publication; MT: multi-cancer CT; RE: review; Other: not a controlled trial, not a CT of TM; G-CSF: Granulocyte colony-stimulating factor.

Fig. 2. Grade 3/4 CIN incidence by number of cycles of oxaliplatin based chemotherapy

t: test groups; c: control groups 

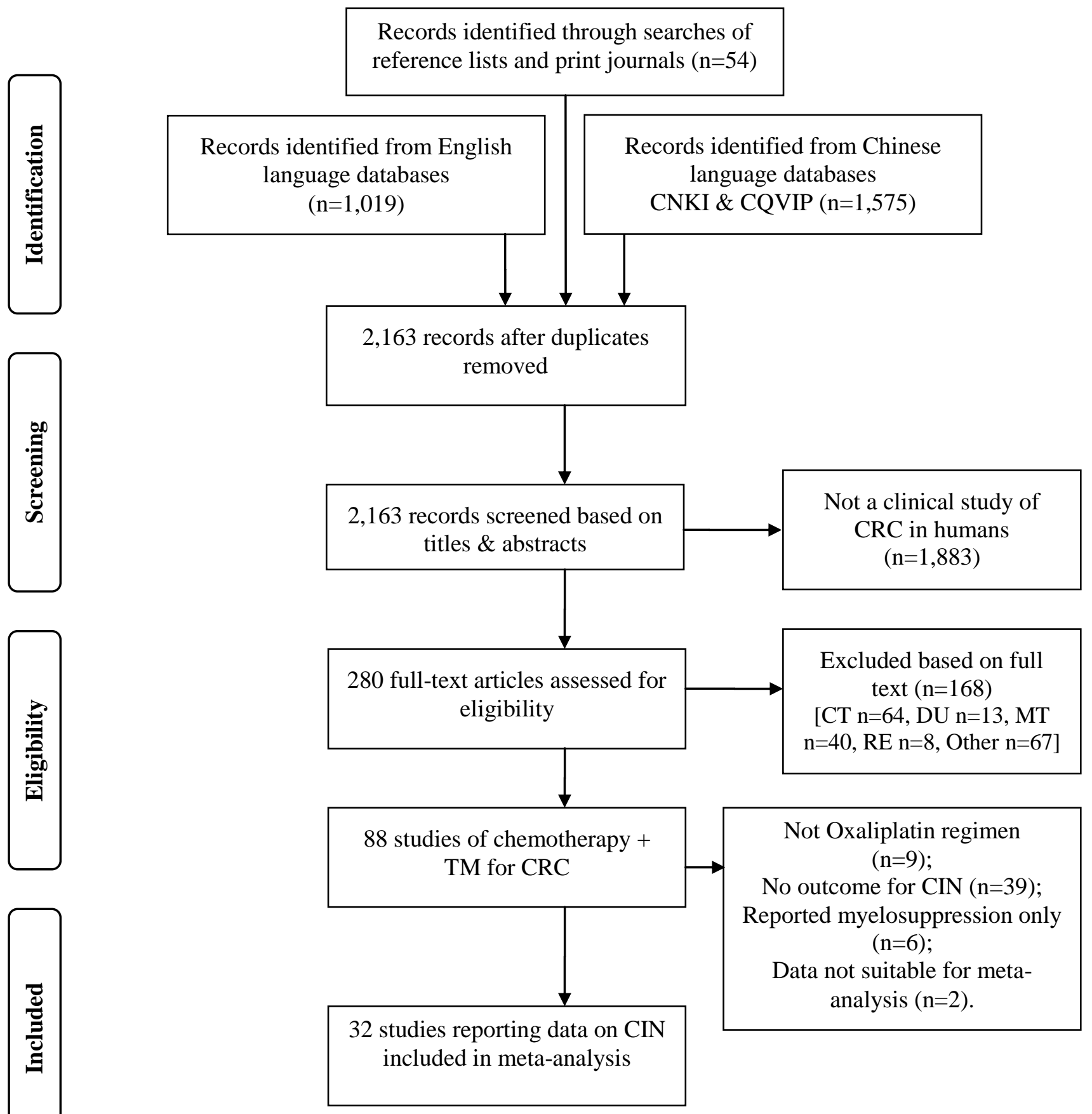

Fig 1.

Records identified through searches of

reference lists and print journals $(n=54)$

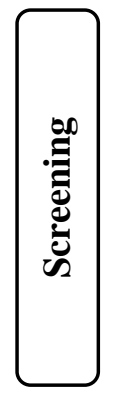

removed

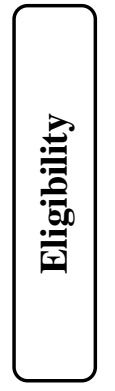

$\mathrm{n}=13, \mathrm{MT}$

$=40, \mathrm{RE} n=8$, Other $\mathrm{n}=67]$

$$
(\mathrm{n}=6) \text {; }
$$

analysis $(n=2)$.

studies reporting data on CIN

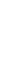




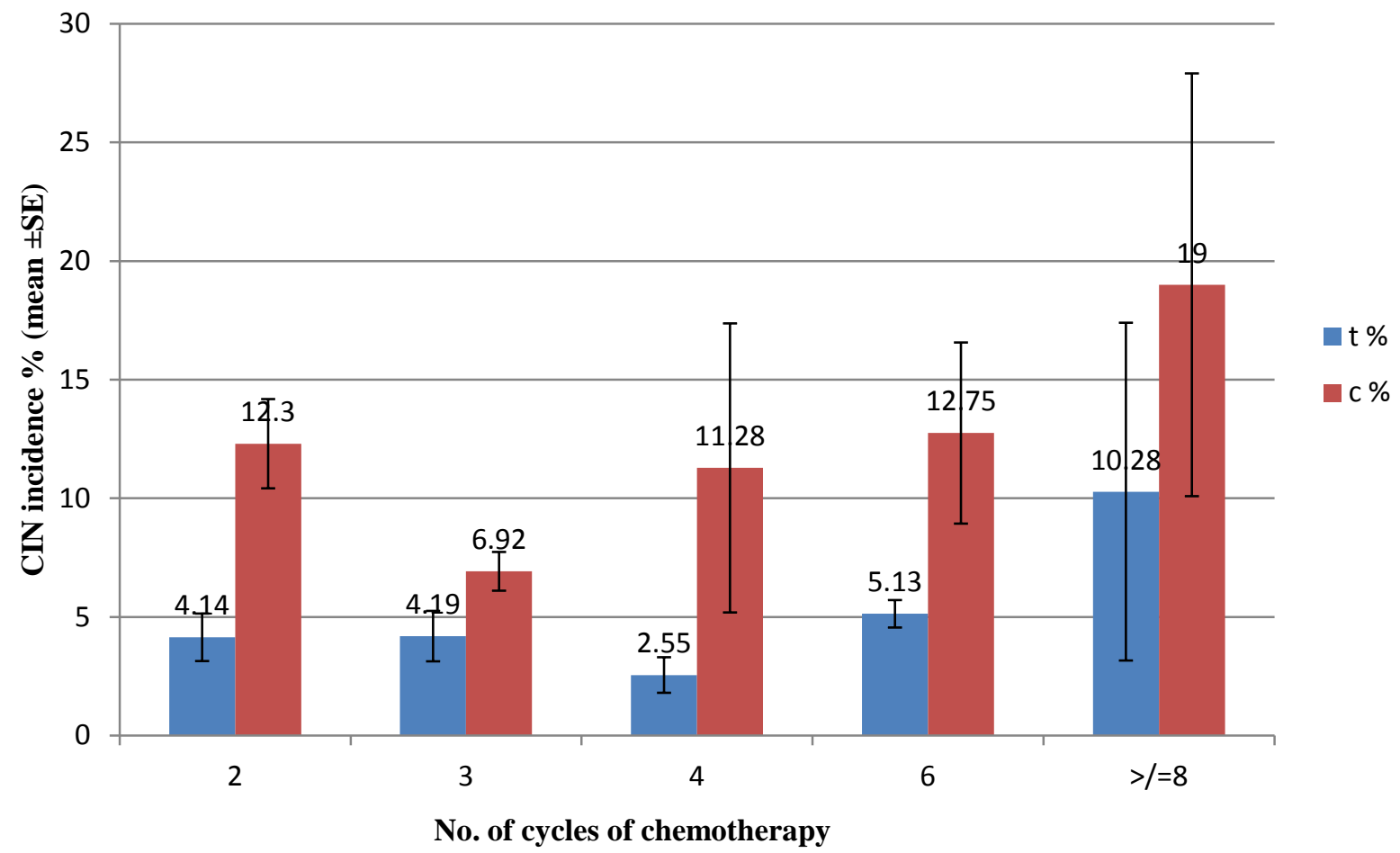

No. of cycles of chemotherapy

\section{Fig. 2.}


Table 1: Characteristics of randomised controlled trials of traditional medicines (TM) combined with oxaliplatin-based regimens for colorectal cancer (CRC) with CIN incidence as an outcome

\begin{tabular}{|c|c|c|c|c|c|}
\hline $\begin{array}{l}\text { Firs } \\
\text { t } \\
\text { aut } \\
\text { hor } \\
\text { (yea } \\
\text { r). }\end{array}$ & $\begin{array}{l}\text { Sample size } \\
\text { T/C; Gender } \\
\text { (M) T/C; Age } \\
\text { T/C }\end{array}$ & $\begin{array}{l}\text { TNM (T/C); } \\
\text { KPS/ ECOG }\end{array}$ & $\begin{array}{l}\text { TM Intervention; } \\
\text { dosage \& duration }\end{array}$ & $\begin{array}{l}\text { Oxaliplatin regimen; dose, } \\
\text { cycles }(\mathrm{T} / \mathrm{C})\end{array}$ & $\begin{array}{l}\text { Outcom } \\
\text { e: CIN } \\
\text { gr.: T/C }\end{array}$ \\
\hline $\begin{array}{l}\text { Den } \\
\text { g D } \\
(201 \\
0)^{33}\end{array}$ & $\begin{array}{l}18 / 18 ; 9 / 9 ; \\
54.17 \pm 10.04 / 5 \\
3.56 \pm 11.10\end{array}$ & $\begin{array}{l}\text { IV (all); KPS } \\
\geq 60 .\end{array}$ & $\begin{array}{l}\text { Yiqixiaoji decoction; } \\
\text { one decoction per day, } \\
\text { for up to } 6 \text { wks. }\end{array}$ & $\begin{array}{l}\text { XELOX: Ox. } 130 \mathrm{mg} / \mathrm{m}^{2}, 2 \text { hours } \\
\text { ID, day } 1 \text {; Xel. } 850 \mathrm{mg} / \mathrm{m}^{2} \text {, bid, } \\
\text { for } 14 \text { days; } 21 \text { days } / \text { cycle, for } 2 \\
\text { cycles; G-CSF used. }\end{array}$ & $\begin{array}{l}\text { I: } 2 / 4 ; \mathrm{II}: \\
1 / 1 ; \\
\text { III: } \\
0 / 1 ; \mathrm{IV}: \\
0 / 0\end{array}$ \\
\hline $\begin{array}{l}\text { Din } \\
\text { g X } \\
(201 \\
0)^{46}\end{array}$ & $\begin{array}{l}\text { 30/30; } 18 / 20 \\
64.5 / 63 \text { (med.) }\end{array}$ & $\begin{array}{l}\text { ACRC (all); } \\
\text { KPS } \geqslant 70\end{array}$ & $\begin{array}{l}\text { Co-Kushen injection; } \\
20 \mathrm{ml}, \mathrm{ID} \text {, day } 1-7,14 \\
\text { day/cycle, for } 8 \\
\text { cycles. }\end{array}$ & $\begin{array}{l}\text { FOLFOX4: Ox.85 mg/m², } 2 \\
\text { hours ID, day } 1, \mathrm{LV} 200 \mathrm{mg} / \mathrm{m}^{2} \text {, } \\
\text { ID, day } 1-2,5-\mathrm{FU} 400 \mathrm{mg} / \mathrm{m}^{2} \text {, } \\
\text { bolus, } 600 \mathrm{mg} / \mathrm{m}^{2}, \text { ID }, 22 \text { hours, } \\
\text { day } 1-2,8 / 8 \text { cycles. }\end{array}$ & $\begin{array}{l}\text { I: } \\
9 / 10 ; \mathrm{II}: \\
3 / 6 \\
\text { III: } \\
0 / 1 ; \mathrm{IV}: \\
0 / 0\end{array}$ \\
\hline $\begin{array}{l}\text { Fan } \\
\text { g M } \\
(200 \\
8)^{34}\end{array}$ & $\begin{array}{l}48 / 45 ; 30 / 28 \\
59.5 \pm \\
11.3 / 56.4 \pm \\
10.3\end{array}$ & $\begin{array}{l}\text { IV(all); KPS } \\
\geq 70 .\end{array}$ & $\begin{array}{l}\text { Javanica oil emulsion } \\
\text { injection; } 30 \mathrm{ml} \text {, ID, } \\
\text { day } 1-14 \text { / cycles, for } \\
\text { two cycles }\end{array}$ & $\begin{array}{l}\text { FOLFOX 4: Ox. } 85 \mathrm{mg} / \mathrm{m}^{2}, 2 \\
\text { hours ID, day } 1, \mathrm{LV} 200 \mathrm{mg} / \mathrm{m}^{2} \text {, } \\
\text { ID, day } 1-2,5-\mathrm{FU} 400 \mathrm{mg} / \mathrm{m}^{2} \text {, } \\
\text { bolus, } 600 \mathrm{mg} / \mathrm{m}^{2}, \text { ID } 22 \text { hours, } \\
\text { day1-2. } 2 / 2 \text { cycles; G-CSF used. }\end{array}$ & $\begin{array}{l}\text { I/II: } \\
19 / 17 \\
\text { III/IV: } \\
2 / 1\end{array}$ \\
\hline $\begin{array}{l}\mathrm{Hu} \\
\mathrm{A} \\
(200 \\
6)^{84}\end{array}$ & $\begin{array}{l}28 / 22 ; 18 / 14 \\
49.3 \pm 4.5 / 48.5 \\
\pm 4.3\end{array}$ & $\begin{array}{l}\text { IV (all); KPS } \\
\geqslant 50 .\end{array}$ & $\begin{array}{l}\text { Treatment with } 4 \\
\text { different TM } \\
\text { decoctions according } \\
\text { to symptom } \\
\text { differentiation; one } \\
\text { decoction per day, for } \\
\text { more than } 30 \text { days. }\end{array}$ & $\begin{array}{l}\text { FOLFOX: Ox. } 130 \mathrm{mg} / \mathrm{m}^{2}, \text { ID, } \\
\text { day } 1, \mathrm{LV} 200 \mathrm{mg} / \mathrm{m}^{2}, \mathrm{ID} \text {, day } 1 \text { - } \\
2,5-F U 2400 \mathrm{mg} / \mathrm{m}^{2}, \text { ID, } 46 \\
\text { hours, cycle } / 21 \text { days, } 2 / 2 \text { cycles. }\end{array}$ & $\begin{array}{l}\text { I: } 4 / 7 ; \text { II: } \\
2 / 6 ; \\
\text { III: } \\
0 / 1 ; \text { IV: } \\
0 / 0\end{array}$ \\
\hline $\begin{array}{l}\text { Kon } \\
\text { o T } \\
(201 \\
3)^{37} \text {. }\end{array}$ & $\begin{array}{l}44 / 45 ; 23 / 25 \\
67 / 61 \text { (med) }\end{array}$ & $\begin{array}{l}\text { NS; ECOG 0- } \\
1\end{array}$ & $\begin{array}{l}\text { TJ-107 Goshajinkigan } \\
\text { aqueous extracts; or } \\
\text { placebo was } \\
\text { administered orally, } \\
\text { tid, before each meal } \\
\text { ( } 7.5 \mathrm{~g} / \text { day) for } 26 \mathrm{wss}\end{array}$ & $\begin{array}{l}\text { FOLFOX4: Ox. } 85 \mathrm{mg} / \mathrm{m}^{2}, 2 \\
\text { hours ID, day } 1, \mathrm{LV} 200 \mathrm{mg} / \mathrm{m}^{2} \text {, } \\
\text { ID, day } 1-2,5-F U \text { 400mg } / \mathrm{m}^{2}, \\
\text { bolus, } 600 \mathrm{mg} / \mathrm{m}^{2}, \text { ID }, 22 \text { hours, } \\
\text { day1-2 or mFOLFOX6: Ox.85 } \\
\mathrm{mg} / \mathrm{m}^{2}, \text { ID, day } 1, \mathrm{LV} 200 \mathrm{mg} \\
/ \mathrm{m}^{2}, \mathrm{ID}, 5-\mathrm{FU} 400 \mathrm{mg} \text { bolus, } \\
\text { follow } 2400 \mathrm{mg} / \mathrm{m}^{2} \text {, ID for } 46 \\
\text { hours, } 14 \text { days } / \mathrm{cycle}, 8 / 8 \text { cycles } \\
\text { or more. }\end{array}$ & $\begin{array}{l}\text { All gr.: } \\
15 / 21 ; \\
\geqslant \\
\text { III: } 10 / 15\end{array}$ \\
\hline $\begin{array}{l}\text { Lao } \\
\text { G } \\
(201 \\
2)^{85}\end{array}$ & $\begin{array}{l}30 / 30 ; 21 / 23 \\
35.1 \pm 20.2 / 36 \\
7 \pm 20.1\end{array}$ & $\begin{array}{l}\text { II } 5 / 7, \text { III: } \\
15 / 14, \\
\text { IV:10/9; KPS } \\
\geqslant 60\end{array}$ & $\begin{array}{l}\text { Jianpijiedu decoction; } \\
\text { one decoction per day, } \\
21 \text { days /cycle, for two } \\
\text { cycles. }\end{array}$ & $\begin{array}{l}\text { FOLFOX: Ox. } 130 \mathrm{mg} / \mathrm{m}^{2}, \mathrm{ID}, \\
\text { day } 1, \mathrm{LV} 200 \mathrm{mg} / \mathrm{m}^{2}, \mathrm{ID} \text {, day } 1 \text {, } \\
5 \text {-FU } 500 \mathrm{mg} \text { bolus day } 1 \text {, } \\
2400 \mathrm{mg} / \mathrm{m}^{2}, \mathrm{ID}, 48 \text { hours, day } 1- \\
2,21 \text { days } / \text { cycle, } 2 / 2 \text { cycles. }\end{array}$ & $\begin{array}{l}\text { I: } 4 / 9 ; \mathrm{II}: \\
3 / 5 \\
\text { III: } \\
1 / 4 ; \mathrm{IV}: \\
0 / 0\end{array}$ \\
\hline $\begin{array}{l}\mathrm{Li} \mathrm{H} \\
(200 \\
7)^{48}\end{array}$ & $\begin{array}{l}\text { 65/52;43/36; } \\
\text { 58/59 (med.) }\end{array}$ & $\begin{array}{l}\text { III: } 27 / 19 \\
\text { IV:38/33; } \\
\text { KPS } \geqslant 60\end{array}$ & $\begin{array}{l}\text { Aidi injection; } 60 \mathrm{ml}, \\
\text { ID, day } 1-10,14 \\
\text { days/cycle, for } 11 \mathrm{wks} \text {. }\end{array}$ & $\begin{array}{l}\text { FOLFOX4: Ox. } 85 \mathrm{mg} / \mathrm{m}^{2}, 2 \\
\text { hours ID, day } 1, \mathrm{LV} 200 \mathrm{mg} / \mathrm{m}^{2} \text {, } \\
\text { ID, day } 1-2,5-\mathrm{FU} 400 \mathrm{mg} / \mathrm{m}^{2} \\
\text { bolus, } 600 \mathrm{mg} / \mathrm{m}^{2}, \text { ID }, 22 \text { hours, } \\
\text { day1-2, 5.5/5.5 cycles (mean). }\end{array}$ & $\begin{array}{l}\text { I: } \\
\text { 9/14;II: } \\
5 / 7 \\
\text { III: } \\
\text { 3/5;IV: } \\
0 / 1 \\
\end{array}$ \\
\hline $\begin{array}{l}\text { Li Y } \\
(200 \\
7)^{39}\end{array}$ & $\begin{array}{l}20 / 18 ; 22 \\
\text { (all); } 72.2 \\
\text { (med. all) }\end{array}$ & $\begin{array}{l}\text { III: } 15, \text { IV: } 23 \\
\text { (all); KPS } \geqslant \\
60\end{array}$ & $\begin{array}{l}\text { Wenshenjianpi } \\
\text { decoction; one } \\
\text { decoction per day, for } \\
10-12 \text { wks. }\end{array}$ & $\begin{array}{l}\text { FOLFOX4: Ox. } 85 \mathrm{mg} / \mathrm{m}^{2}, 2 \\
\text { hours ID, day } 1, \mathrm{LV} 200 \mathrm{mg} / \mathrm{m}^{2} \text {, } \\
\text { ID, day } 1-2,5-\mathrm{FU} 400 \mathrm{mg} / \mathrm{m}^{2} \text {, } \\
\text { bolus, } 600 \mathrm{mg} / \mathrm{m}^{2}, \mathrm{ID}, 22 \mathrm{hours}, \\
\text { day1-2, 6/5.5 cycles (med.). }\end{array}$ & $\begin{array}{l}\text { I: } \\
5 / 10 ; \mathrm{II}: \\
4 / 4 \\
\text { III: } \\
1 / 1 ; \mathrm{IV}: \\
0 / 0\end{array}$ \\
\hline $\begin{array}{l}\text { Lim } \\
\text { M } \\
(201 \\
2)^{86}\end{array}$ & $\begin{array}{l}24 / 23 ; 17 / 14 ; \\
56.89 \pm 14.77 / 5 \\
5.37 \pm 16.01\end{array}$ & $\begin{array}{l}\text { III: } 15 / 16, \text { IV: } \\
9 / 7 ; \text { KPS } \\
84.78 \pm 14.66 / \\
83.42 \pm 13.09 \\
\end{array}$ & $\begin{array}{l}\text { Pianzaihuang capsule; } \\
\text { two capsules, bid; } 14 \\
\text { days/cycle, } 8-10 \\
\text { cycles. }\end{array}$ & $\begin{array}{l}\text { FOLFOX4: Ox. } 85 \mathrm{mg} / \mathrm{m}^{2}, 2 \\
\text { hours ID, day } 1, \mathrm{LV} 200 \mathrm{mg} / \mathrm{m}^{2} \text {, } \\
\text { ID, day } 1-2,5-F U \text { 400mg } / \mathrm{m}^{2}, \\
\text { bolus, } 600 \mathrm{mg} / \mathrm{m}^{2}, \text { ID, } 22 \text { hours, }\end{array}$ & $\begin{array}{l}\text { I: } 5 / 7 ; \text { II: } \\
1 / 4 ; \\
\text { III: } \\
0 / 1 ; \mathrm{IV}:\end{array}$ \\
\hline
\end{tabular}




\begin{tabular}{|c|c|c|c|c|c|}
\hline & & & & day1-2, 8-10/8-10 cycles. & $0 / 0$ \\
\hline $\begin{array}{l}\text { Liu } \\
\text { H } \\
(200 \\
9)^{87} .\end{array}$ & $\begin{array}{l}\text { 36/34; 16/18; } \\
50.2 \text { (med. all) }\end{array}$ & $\begin{array}{l}\text { ACRC (all); } \\
\text { KPS } \geqslant 60\end{array}$ & $\begin{array}{l}\text { Kang'ai fangyi pian; } \\
\text { one decoction per day, } \\
21 \text { days / cycle, for } 3 \\
\text { cycles. }\end{array}$ & $\begin{array}{l}\text { FOLFOX: Ox. } 130 \mathrm{mg} / \mathrm{m}^{2}, \text { ID, } \\
\text { day } 1, \mathrm{LV} 200 \mathrm{mg} / \mathrm{m}^{2}, \mathrm{ID} \text {, day } 1- \\
5,5-\mathrm{FU} 300 \mathrm{mg} / \mathrm{m}^{2}, \text { ID, day } 1-5, \\
21 \text { days } / \text { cycle, } 3 / 3 \text { cycles. }\end{array}$ & $\begin{array}{l}\text { I: } 7 / 9 ; \text { II: } \\
2 / 5 \\
\text { III: } \\
1 / 1 ; \text { IV: } \\
0 / 0\end{array}$ \\
\hline $\begin{array}{l}\text { Liu } \\
\mathrm{J}(20 \\
05)^{8} \\
8\end{array}$ & $\begin{array}{l}43 / 21 ; 23 / 10 \\
61.52 \pm 10.12 \\
/ 60.11 \pm 9.78\end{array}$ & $\begin{array}{l}\text { IV (all); KPS } \\
\geqslant 50 .\end{array}$ & $\begin{array}{l}\text { Jianpihuoxue } \\
\text { formulae; one } \\
\text { decoction per day, } 30 \\
\text { days/ cycle, } 3 \text { cycles. }\end{array}$ & $\begin{array}{l}\text { FOLFOX: Ox. } 150 \mathrm{mg} / \mathrm{m}^{2}, \text { ID, } \\
\text { day } 1 \text {, LV } 200 \mathrm{mg} / \mathrm{m}^{2}, \mathrm{ID} \text {, day } 1- \\
5,5-\mathrm{FU} 500 \mathrm{mg} / \mathrm{m}^{2}, \mathrm{ID} \text {, day } 1-5 \text {, } \\
30 \text { days/ cycle, } 3 / 3 \text { cycles. }\end{array}$ & $\begin{array}{l}\text { I: } 5 / 5 ; \mathrm{II}: \\
2 / 3 ; \\
\text { III: } \\
1 / 1 ; \mathrm{IV}: \\
0 / 0\end{array}$ \\
\hline $\begin{array}{l}\text { Liu } \\
\text { W } \\
(201 \\
1)^{89}\end{array}$ & $\begin{array}{l}\text { 16/16; 11/10; } \\
\text { 51/52(mean) }\end{array}$ & $\begin{array}{l}\text { IV (all); KPS } \\
\text { 40-60(range). }\end{array}$ & $\begin{array}{l}\text { Yierkang capsule; } 4-6 \\
\text { capsules, bid, for 5-25 } \\
\text { months. }\end{array}$ & $\begin{array}{l}\text { FOLFOX: Ox.130 mg/m², ID, } \\
\text { day } 1, \text { LV } 100 \mathrm{mg} / \mathrm{m}^{2}, \mathrm{ID} \text {, day } 1- \\
5,5-\mathrm{FU} 400 \mathrm{mg} / \mathrm{m}^{2}, \mathrm{ID} \text {, day } 1-5 \text {, } \\
21 \text { days } / \text { cycle, } 6 / 6 \text { cycles. }\end{array}$ & $\begin{array}{l}\text { All gr.: } \\
3 / 12 \text {. }\end{array}$ \\
\hline $\begin{array}{l}\text { Ma } \\
\text { J } \\
(200 \\
5)^{90}\end{array}$ & $\begin{array}{l}28 / 25 ; 15 / 13 ; \\
58.1 / 57.5(\text { mea } \\
\text { n) }\end{array}$ & $\begin{array}{l}\text { II:7/4, } \\
\text { III: } \\
21 / 21 ; \mathrm{KPS} \geqslant \\
60 .\end{array}$ & $\begin{array}{l}\text { Jianpi Xiaoliu } \\
\text { decoction; one } \\
\text { decoction per day, } 90 \\
\text { days/ cycle, } 2 \text { cycles. }\end{array}$ & $\begin{array}{l}\text { FOLFOX: Ox. } 130 \mathrm{mg} / \mathrm{m}^{2}, \mathrm{ID}, \\
\text { day } 1, \mathrm{LV} 200 \mathrm{mg} / \mathrm{m}^{2}, \mathrm{ID} \text {, day } 1- \\
5,5-\mathrm{FU} 375 \mathrm{mg} / \mathrm{m}^{2}, \mathrm{ID} \text {, day } 1-5 \text {, } \\
21 \text { days } / \text { cycle, } 6 / 6 \text { cycles. }\end{array}$ & $\begin{array}{l}\text { I: } 4 / 8 ; \mathrm{II}: \\
2 / 2 \\
\text { III: } \\
0 / 0 ; \mathrm{IV}: \\
0 / 0\end{array}$ \\
\hline $\begin{array}{l}\text { Qiu } \\
\text { Z } \\
(201 \\
1)^{50}\end{array}$ & $\begin{array}{l}22 / 21 ; 14 / 13 \\
56.9 / 52.7(\mathrm{med} \\
.)\end{array}$ & $\begin{array}{l}\text { IV (all);KPS } \\
\geqslant 60 .\end{array}$ & $\begin{array}{l}\text { Kang'ai injection; } 40 \\
\text { ml, ID, day } 1-10,14 \\
\text { days/ cycle, for } 4 \\
\text { cycles. }\end{array}$ & $\begin{array}{l}\text { FOLFOX4: Ox. } 85 \mathrm{mg} / \mathrm{m}^{2}, 2 \\
\text { hours ID, day } 1, \mathrm{LV} 200 \mathrm{mg} / \mathrm{m}^{2}, \\
\text { ID, day } 1-2,5-\mathrm{FU} 400 \mathrm{mg} / \mathrm{m}^{2}, \\
\text { bolus, } 600 \mathrm{mg} / \mathrm{m}^{2}, \mathrm{ID}, 22 \text { hours, } \\
\text { day1-2, } 21 \text { days } / \text { cycle, } 4 / 4 \\
\text { cycles. }\end{array}$ & $\begin{array}{l}\text { III/IV: } \\
1 / 8 .\end{array}$ \\
\hline $\begin{array}{l}\text { Son } \\
\text { g W } \\
(201 \\
2)^{91}\end{array}$ & $\begin{array}{l}20 / 20 ; 12 / 13 \\
56.4 \pm 9.1 \\
/ 48.3 \pm 8.2\end{array}$ & $\begin{array}{l}\text { ACRC (all); } \\
\text { KPS } \geqslant 70 .\end{array}$ & $\begin{array}{l}\text { Xiaoliuhuajichangfan } \\
\text { g II; one decoction per } \\
\text { day, } 21 \text { days/ cycle, } 2 \\
\text { cycles. }\end{array}$ & $\begin{array}{l}\text { FOLFOX: Ox. } 135 \mathrm{mg} / \mathrm{m}^{2}, \text { ID, } \\
\text { day } 1 \text {, LV } 200 \mathrm{mg} / \mathrm{m}^{2} \text {, ID, day } 1- \\
\text { 2, 5-FU } 2400 \mathrm{mg} / \mathrm{m}^{2} \text {, ID, for } 48 \\
\text { hours, } 21 \text { days } / \text { cycle, } 2 / 2 \text { cycles. }\end{array}$ & $\begin{array}{l}\text { I: } 2 / 4 ; \mathrm{II}: \\
3 / 3 \\
\text { III: } \\
1 / 2 ; \mathrm{IV}: \\
0 / 1\end{array}$ \\
\hline $\begin{array}{l}\text { Tao } \\
\text { C } \\
(201 \\
3)^{47}\end{array}$ & $\begin{array}{l}74 / 74 ; 51 / 50 \\
60.1+7.9 \\
/ 60.4+8.9\end{array}$ & $\begin{array}{l}\text { ACRC (all); } \\
\text { KPS } \\
65.6+12.3 / 66 \\
7+14.5\end{array}$ & $\begin{array}{l}\text { Co-kushen injection; } \\
15 \text { ml per day, } \\
\text { ID,started } 14 \text { days } \\
\text { before chemotherapy, } \\
5 \text { wks/cycle, for } 3 \\
\text { cycle. }\end{array}$ & $\begin{array}{l}\text { FOLFOX: Ox. } 135 \mathrm{mg} / \mathrm{m}^{2}, \mathrm{ID}, \\
\text { day } 1, \mathrm{LV} \text { 200mg/m } / \mathrm{m}^{2}, \mathrm{ID}, 2 \\
\text { hours, day } 1-5,5-\mathrm{FU} \\
500 \mathrm{mg} / \mathrm{m}^{2}, \mathrm{ID}, 8-10 \text { hours, day } 1- \\
5,3 \mathrm{wks} / \text { cycle, } 3 / 3 \text { cycle. }\end{array}$ & $\begin{array}{l}\text { I: } \\
\text { 10/14;II: } \\
\text { 5/16; } \\
\text { III: } \\
\text { 5/5;IV: } \\
0 / 0 \text {. }\end{array}$ \\
\hline $\begin{array}{l}\text { Wan } \\
\text { g H } \\
(200 \\
8)^{92}\end{array}$ & $\begin{array}{l}34 / 34 ; 20 / 22 \\
52.58 \pm 8.12 / 51 \\
.11 \pm 7.72\end{array}$ & $\begin{array}{l}\text { IV:34/34; } \\
\text { KPS } \geqslant 50 .\end{array}$ & $\begin{array}{l}\text { Yiqiguoxiebuchang } \\
\text { decoction; one } \\
\text { decoction per day, for } \\
3 \text { mths. }\end{array}$ & $\begin{array}{l}\text { FOLFOX: Ox. } 85 \mathrm{mg} / \mathrm{m}^{2}, \text { ID, day } \\
1, \mathrm{LV} 200 \mathrm{mg} / \mathrm{m}^{2}, \mathrm{ID} \text {, day } 1-2,5- \\
\text { FU } 500 \mathrm{mg} \text { bolus day } 1,5-\mathrm{FU} \\
2500 \mathrm{mg} / \mathrm{m}^{2}, \mathrm{ID} \text {, for } 48 \text { hours, } 21 \\
\text { days/ cycle, } 4 / 4 \text { cycles. }\end{array}$ & $\begin{array}{l}\text { I: 4/8;II: } \\
2 / 5 ; \\
\text { III: } \\
1 / 2 ; \text { IV: } \\
0 / 0\end{array}$ \\
\hline $\begin{array}{l}\text { Wan } \\
\text { g J } \\
(201 \\
1)^{93}\end{array}$ & $\begin{array}{l}30 / 30 ; 18 / 21 \\
52.3 \pm 6.2 / \\
56.7 \pm 7.8\end{array}$ & $\begin{array}{l}\text { ACRC (all); } \\
\text { KPS } \geqslant 60 .\end{array}$ & $\begin{array}{l}\text { Yichangning } \\
\text { decoction; one } \\
\text { decoction per day, for } \\
2 \text { mths. }\end{array}$ & $\begin{array}{l}\text { FOLFOX4: Ox. } 85 \mathrm{mg} / \mathrm{m}^{2}, 2 \\
\text { hours ID, day } 1, \mathrm{LV} 200 \mathrm{mg} / \mathrm{m}^{2} \text {, } \\
\text { ID, day } 1-2,5-\mathrm{FU} 400 \mathrm{mg} / \mathrm{m}^{2} \text {, } \\
\text { bolus, } 600 \mathrm{mg} / \mathrm{m}^{2}, \mathrm{ID}, 22 \text { hours, } \\
\text { day1-2, } 21 \text { days } / \text { cycle, } 2 / 2 \\
\text { cycles. }\end{array}$ & $\begin{array}{l}\text { I/II: } \\
8 / 14 \\
\text { III/IV: } \\
1 / 5\end{array}$ \\
\hline $\begin{array}{l}\text { Wan } \\
\text { g Y } \\
(201 \\
2)^{49}\end{array}$ & $\begin{array}{l}\text { 38/36; 26/25; } \\
52 \text { (med. all). }\end{array}$ & $\begin{array}{l}\text { ACRC (all); } \\
\text { KPS } \geqslant 70 .\end{array}$ & $\begin{array}{l}\text { Aidi injection; } 80 \mathrm{ml} \text {, } \\
\text { ID, per day, } \\
\text { 10days/cycle,for } 4 \\
\text { cycles. }\end{array}$ & $\begin{array}{l}\text { FOLFOX4: Ox. } 85 \mathrm{mg} / \mathrm{m}^{2}, 2 \\
\text { hours ID, day } 1, \mathrm{LV} 200 \mathrm{mg} / \mathrm{m}^{2} \text {, } \\
\text { ID, day } 1-2,5-\mathrm{FU} 400 \mathrm{mg} / \mathrm{m}^{2} \text {, } \\
\text { bolus, } 600 \mathrm{mg} / \mathrm{m}^{2}, \text { ID }, 22 \text { hours, } \\
\text { day } 1-2,4 / 4 \text { cycles. }\end{array}$ & $\begin{array}{l}\text { All gr.: } \\
21 / 28 \text {. }\end{array}$ \\
\hline $\begin{array}{l}\text { Wan } \\
\text { g Y } \\
(201 \\
3)^{38}\end{array}$ & $\begin{array}{l}32 / 30 ; 20 / 19 ; \\
\text { NS. }\end{array}$ & $\begin{array}{l}\text { ACRC (all); } \\
\text { KPS } \geqslant 70 .\end{array}$ & $\begin{array}{l}\text { Xiaoaiping injection; } \\
60 \mathrm{ml}, \mathrm{ID}, \text { per day, } 14 \\
\text { days/ cycle, for two } \\
\text { cycles. }\end{array}$ & XELOX: no details, $2 / 2$ cycles. & $\begin{array}{l}\text { All gr.: } \\
20 / 26 .\end{array}$ \\
\hline $\begin{array}{l}\mathrm{Wu} \\
\mathrm{G}(2 \\
010) \\
94\end{array}$ & $\begin{array}{l}33 / 25 ; 23 / 17 \\
55.4 \pm 13.6 \\
/ 52.8 \pm 15.2\end{array}$ & $\begin{array}{l}\text { I: } 5 / 3, \text { II: } 10 / 8, \\
\text { III: } 15 / 11 \\
\text { IV:3/3; KPS } \\
\geqslant 60\end{array}$ & $\begin{array}{l}\text { Fupiyiwei decoction; } \\
\text { one decoction per day, } \\
\text { for } 24 \text { wks. }\end{array}$ & $\begin{array}{l}\text { FOLFOX 4: Ox. } 85 \mathrm{mg} / \mathrm{m}^{2}, 2 \\
\text { hours ID, day } 1, \mathrm{LV} 200 \mathrm{mg} / \mathrm{m}^{2} \text {, } \\
\text { ID, day } 1-2,5-F U ~ 400 \mathrm{mg} / \mathrm{m}^{2} \text {, } \\
\text { bolus, } 600 \mathrm{mg} / \mathrm{m}^{2}, \text { ID }, 22 \text { hours, } \\
\text { day } 1-2,12 / 12 \text { cycles. }\end{array}$ & $\begin{array}{l}\text { I: } 7 / 8 ; \mathrm{II}: \\
2 / 6 ; \\
\text { III: } \\
1 / 3 ; \mathrm{IV}: \\
0 / 0\end{array}$ \\
\hline $\begin{array}{l}\mathrm{Xu} \\
\mathrm{Y} \\
(201 \\
\end{array}$ & $\begin{array}{l}61 / 60 ; 38 / 37 ; \\
53 / 52 \text { (mean, } \\
\text { all) }\end{array}$ & $\begin{array}{l}\text { ACRC (all); } \\
\geq 70\end{array}$ & $\begin{array}{l}\text { Jiangniling formula; } \\
\text { one decoction per day, } \\
14 \text { days/cycle, for } 8 \text { - } \\
\end{array}$ & $\begin{array}{l}\text { FOLFOX 4: Ox. } 85 \mathrm{mg} / \mathrm{m}^{2}, 2 \\
\text { hours ID, day } 1, \mathrm{LV} 200 \mathrm{mg} / \mathrm{m}^{2} \text {, } \\
\text { ID, day } 1-2,5-\mathrm{FU} 400 \mathrm{mg} / \mathrm{m}^{2} \text {, }\end{array}$ & $\begin{array}{l}5.03 \pm 2.1 \\
4 / 3.03 \pm 1 \\
.27(\text { mean } \\
\end{array}$ \\
\hline
\end{tabular}




\begin{tabular}{|c|c|c|c|c|c|}
\hline 0$)^{35}$. & & & 10 cycles & $\begin{array}{l}\text { bolus, } 600 \mathrm{mg} / \mathrm{m}^{2} \text {, ID, } 22 \text { hours, } \\
\text { day } 1-2,11.1 / 7.8 \text { (mean) cycles. }\end{array}$ & ) \\
\hline $\begin{array}{l}\text { Yan } \\
\text { g C } \\
(200 \\
7)^{95}\end{array}$ & $\begin{array}{l}50 / 50 ; 29 / 27 \\
51.36 \pm 10.58 \\
153.48 \pm 9.35\end{array}$ & $\begin{array}{l}\text { ACRC (all); } \\
\text { KPS } \geqslant 60\end{array}$ & $\begin{array}{l}\text { Jianpikangfu pill; } 6 \mathrm{~g}, \\
\text { tid, for } 4 \text { wks. }\end{array}$ & $\begin{array}{l}\text { FOLFOX: Ox. } 135 \mathrm{mg} / \mathrm{m}^{2}, \text { ID, } \\
\text { day } 1, \mathrm{LV} 100 \mathrm{mg} / \mathrm{m}^{2} \text {, ID, day } 1- \\
5,5-\mathrm{FU} 425 \mathrm{mg} / \mathrm{m}^{2} \text {, ID day } 1-5 \text {, } \\
4 / 4 \text { wks. }\end{array}$ & $\begin{array}{l}\text { I: } \\
\text { 18/18;II: } \\
6 / 14 ; \\
\text { III: } \\
0 / 3 ; \text { IV: } \\
0 / 0\end{array}$ \\
\hline $\begin{array}{l}\text { Yan } \\
\text { g Y } \\
(200 \\
8)^{51}\end{array}$ & $\begin{array}{l}30 / 30 ; 16 / 19 \\
51.07+10.44 \\
151.33+10.95\end{array}$ & $\begin{array}{l}\text { ACRC (all); } \\
\text { KPS } \geqslant 60\end{array}$ & $\begin{array}{l}\text { Kang'ai injection; } 50 \\
\text { ml, ID, day } 1-20, \\
\text { 30days/cycle, for } 2 \\
\text { cycles. }\end{array}$ & $\begin{array}{l}\text { FOLFOX4: Ox.85 mg/m², } \\
\text { hours ID, day } 1, \mathrm{LV} 200 \mathrm{mg} / \mathrm{m}^{2} \text {, } \\
\text { ID, day } 1-2,5-\mathrm{FU} 400 \mathrm{mg} / \mathrm{m}^{2} \text {, } \\
\text { bolus, } 600 \mathrm{mg} / \mathrm{m}^{2}, \text { ID }, 22 \text { hours, } \\
\text { day1-2, } 4 / 4 \text { cycles. }\end{array}$ & $\begin{array}{l}\text { I: } \\
9 / 11 ; \mathrm{II}: \\
2 / 8 \\
\text { III: } \\
1 / 3 ; \mathrm{IV}: \\
0 / 0\end{array}$ \\
\hline $\begin{array}{l}\text { Zen } \\
\text { g C } \\
(201 \\
3)^{36}\end{array}$ & $\begin{array}{l}61 / 30 \\
39 / 19 ; 54.3 \\
\pm 6.3 / 53.2 \pm \\
6.6\end{array}$ & $\begin{array}{l}\text { III: } 20 / 12 \\
\text { IV: } 41 / 18 \\
\text { KPS } \geq 60\end{array}$ & $\begin{array}{l}\text { Fuzhengxiaoji } \\
\text { decoction; one } \\
\text { decoction per day, } 14 \\
\text { days/cycle, for } 4 \\
\text { cycles. }\end{array}$ & $\begin{array}{l}\text { FOLFOX: Ox. } 85 \mathrm{mg} / \mathrm{m}^{2}, \mathrm{ID}, \text { day } \\
1, \mathrm{LV} 200 \mathrm{mg} / \mathrm{m}^{2}, \mathrm{ID} \text {, day } 1-2,5- \\
\text { FU } 360-500 \mathrm{mg} / \mathrm{m}^{2} \text { bolus, } 600 \\
\mathrm{mg} / \mathrm{m}^{2}, \mathrm{ID} \text {, for } 22 \text { hours, day } 1- \\
2,14 \text { days/cycle, } 4 / 4 \text { cycles. }\end{array}$ & $\begin{array}{l}4.56 \pm 1.3 \\
3 / 3.27 \pm 1 \\
.08(\text { mean } \\
)\end{array}$ \\
\hline $\begin{array}{l}\text { Zen } \\
\text { g D } \\
(200 \\
9)^{101} \\
.\end{array}$ & $\begin{array}{l}35 / 32 ; 25 / 21 \\
50<: 4 / 5,51- \\
69: 28 / 25,>70: \\
3 / 2\end{array}$ & $\begin{array}{l}\text { IV (all); KPS } \\
\geqslant 70 .\end{array}$ & $\begin{array}{l}\text { Ginsenoside } \operatorname{Rg} 3 \\
\text { capsules: } 2 \text { capsules, } \\
\text { bid, for } 8 \text { wks. }\end{array}$ & $\begin{array}{l}\text { FOLFOX4: Ox. } 85 \mathrm{mg} / \mathrm{m}^{2}, 2 \\
\text { hours ID, day } 1, \mathrm{LV} 200 \mathrm{mg} / \mathrm{m}^{2} \text {, } \\
\text { ID, day } 1-2,5-\mathrm{FU} 400 \mathrm{mg} / \mathrm{m}^{2}, \\
\text { bolus, } 600 \mathrm{mg} / \mathrm{m}^{2}, \mathrm{ID}, 22 \text { hours, } \\
\text { day } 1-2,21 \text { days } / \text { cycle, } 4 / 4 \\
\text { cycles. }\end{array}$ & $\begin{array}{l}\text { All gr.: } \\
22 / 28 .\end{array}$ \\
\hline $\begin{array}{l}\text { Zen } \\
\text { g J } \\
(200 \\
8)^{96} .\end{array}$ & $\begin{array}{l}\text { 30/30; } 19 / 18 \\
48 / 60 \text { (med.). }\end{array}$ & $\begin{array}{l}\text { ACRC (all); } \\
\text { KPS } \geqslant 60\end{array}$ & $\begin{array}{l}\text { Multi-TM formulae; } \\
\text { one decoction per day, } \\
\text { for } 4 \mathrm{wks} \text {. }\end{array}$ & $\begin{array}{l}\text { FOLFOX 4: Ox. } 85 \mathrm{mg} / \mathrm{m}^{2}, 2 \\
\text { hours ID, day } 1 \text {, LV } 200 \mathrm{mg} / \mathrm{m}^{2} \text {, } \\
\text { ID, day } 1-2,5-F U 400 \mathrm{mg} / \mathrm{m}^{2} \text {, } \\
\text { bolus, } 600 \mathrm{mg} / \mathrm{m}^{2}, \text { ID }, 22 \text { hours, } \\
\text { day } 1-2,2 / 2 \text { cycles. }\end{array}$ & $\begin{array}{l}\text { I: } \\
\text { 12/16;II: } \\
7 / 8 \\
\text { III: } \\
1 / 2 ; \text { IV: } \\
0 / 1\end{array}$ \\
\hline $\begin{array}{l}\text { Zha } \\
\text { ng } \\
\text { Q } \\
(200 \\
6)^{97} .\end{array}$ & $\begin{array}{l}38 / 30 ; 35(\text { all }) \\
54.8(\text { mean } \\
\text { all })\end{array}$ & $\begin{array}{l}\text { ACRC (all); } \\
\text { KPS:76.5 } \pm 5.8 \\
/ 73.5 \pm 6.0\end{array}$ & $\begin{array}{l}\text { Yiqihuoxue formulae; } \\
\text { one decoction per day, } \\
21 \text { days/ cycle, for } 3 \\
\text { cycles. }\end{array}$ & $\begin{array}{l}\text { FOLFOX: Ox. } 125 \mathrm{mg} / \mathrm{m}^{2}, \text { ID, } \\
\text { day } 1, \mathrm{LV} 200 \mathrm{mg} / \mathrm{m}^{2}, \mathrm{ID} \text {, day } 1- \\
2,5 \text {-FU } 500 \mathrm{mg} / \mathrm{m}^{2} \text { bolus, day } 1- \\
2,2000 \mathrm{mg} / \mathrm{m}^{2} \mathrm{ID} \text { for } 72 \text { hours, } \\
21 \text { days/cycle, } 3 / 3 \text { cycles. }\end{array}$ & $\begin{array}{l}\text { I: } 5 / 9 ; \text { II: } \\
2 / 4 ; \\
\text { III: } \\
1 / 1 ; \text { IV: } \\
0 / 0 \text {. }\end{array}$ \\
\hline $\begin{array}{l}\text { Zha } \\
\text { ng } \\
\text { Q } \\
(201 \\
0)^{40} .\end{array}$ & $\begin{array}{l}60 / 60 ; 35 / 33 \\
56.2(\text { mean } \\
\text { all); }\end{array}$ & $\begin{array}{l}\text { ACRC (all); } \\
\text { KPS } \geq 60\end{array}$ & $\begin{array}{l}\text { Gubenxiaoliu capsule; } \\
4 \text { capsules, bid, for } 8 \\
\text { wks. }\end{array}$ & $\begin{array}{l}\text { FOLFOX4: Ox. } 85 \mathrm{mg} / \mathrm{m}^{2}, 2 \\
\text { hours ID, day } 1, \mathrm{LV} 200 \mathrm{mg} / \mathrm{m}^{2} \text {, } \\
\text { ID, day } 1-2,5-\mathrm{FU} \text { 400mg } / \mathrm{m}^{2} \text {, } \\
\text { bolus, } 600 \mathrm{mg} / \mathrm{m}^{2}, \text { ID }, 22 \text { hours, } \\
\text { day1-2, } 4 / 4 \text { cycles. }\end{array}$ & $\begin{array}{l}\text { I: } \\
10 / 7 ; \mathrm{II}: \\
3 / 8 \\
\text { III: } \\
2 / 6 ; \mathrm{IV}: \\
0 / 0 \text {. }\end{array}$ \\
\hline $\begin{array}{l}\text { Zha } \\
\text { ng } \\
\text { W } \\
(201 \\
3)^{98} \text {. }\end{array}$ & $\begin{array}{l}32 / 32 ; 15 / 16 \\
56.8 \pm 10.1 / 46 \\
4 \pm 9.2\end{array}$ & $\begin{array}{l}\text { II: } 23 / 22 ; \text { III: } \\
9 / 10 \\
\text { KPS } \geqslant 70\end{array}$ & $\begin{array}{l}\text { Xiaoliuhuaji decoction } \\
\text { I; one decoction per } \\
\text { day, for } 5 \mathrm{mths} \text {. }\end{array}$ & $\begin{array}{l}\text { FOLFOX: Ox. } 135 \mathrm{mg} / \mathrm{m}^{2}, \text { ID, } \\
\text { day } 1, \mathrm{LV} 200 \mathrm{mg} / \mathrm{m}^{2}, \text { ID, day } 1- \\
2,5-F U 2400 \mathrm{mg} / \mathrm{m}^{2}, \text { ID for } 48 \\
\text { hours, } 21 \text { days } / \text { cycle, } 6 / 6 \text { cycles. }\end{array}$ & $\begin{array}{l}\text { I: } 6 / 8 ; \mathrm{II}: \\
4 / 7 ; \\
\text { III: } \\
1 / 4 ; \mathrm{IV}: \\
0 / 2\end{array}$ \\
\hline $\begin{array}{l}\text { Zha } \\
\text { ng } \\
\text { Y } \\
(201 \\
0)^{99} \text {. }\end{array}$ & $\begin{array}{l}\text { 21/20; NS; } \\
\text { NS; }\end{array}$ & $\begin{array}{l}\text { ACRC (all); } \\
\text { KPS } \geqslant 60 .\end{array}$ & $\begin{array}{l}\text { Jianpijiedu decoction; } \\
\text { one decoction per day, } \\
\text { for } 4 \text { wks. }\end{array}$ & $\begin{array}{l}\text { FOLFOX 4: Ox. } 85 \mathrm{mg} / \mathrm{m}^{2}, 2 \\
\text { hours ID, day } 1, \mathrm{LV} 200 \mathrm{mg} / \mathrm{m}^{2} \text {, } \\
\text { ID, day } 1-2,5-\mathrm{FU} 400 \mathrm{mg} / \mathrm{m}^{2} \text {, } \\
\text { bolus, } 600 \mathrm{mg} / \mathrm{m}^{2}, \text { ID }, 22 \text { hours, } \\
\text { day } 1-2,2 / 2 \text { cycles. }\end{array}$ & $\begin{array}{l}\text { I/II: } 4 / 8 \\
\text { III/IV: } \\
1 / 3\end{array}$ \\
\hline $\begin{array}{l}\text { Zho } \\
\text { u J } \\
(201 \\
1)^{100}\end{array}$ & $\begin{array}{l}34 / 34 ; 22 / 20 \\
51.2 / 52.5\end{array}$ & $\begin{array}{l}\text { II: } 14 / 13, \text { III: } \\
16 / 11, \text { IV:6/5; } \\
\text { KPS } \geq 60\end{array}$ & $\begin{array}{l}\text { Fuzhengjianpi } \\
\text { decoction; one } \\
\text { decoction per day, for } \\
8 \text { wks. }\end{array}$ & $\begin{array}{l}\text { FOLFOX: Ox. } 130 \mathrm{mg} / \mathrm{m}^{2}, \text { ID, } \\
\text { day } 1 \text {, LV } 100 \mathrm{mg} / \mathrm{m}^{2}, \mathrm{ID} \text {, day } 1- \\
5,5-\mathrm{FU} 500 \mathrm{mg} / \mathrm{m}^{2} \text {, ID, day } 1-5 \text {, } \\
28 \text { days/cycle, } 2 / 2 \text { cycles. }\end{array}$ & $\begin{array}{l}\text { I: } 1 / 6 ; \mathrm{II}: \\
3 / 7 ; \\
\text { III: } \\
3 / 4 ; \mathrm{IV}: \\
0 / 2\end{array}$ \\
\hline
\end{tabular}

RN: reference number (superscript), T: treatment group, C: control group, M: male, N: number, CIN:

chemotherapy induced neutropenia, gr.: WHO recommendations for grading of acute and subacute toxicity grade, NS: not stated, ID: intravenous drip, TNM: cancer staging system. ' $T$ ' for tumor, denotes the extent of invasion of the intestinal wall, ' $\mathrm{N}$ ' for lymphatic node, the amount of lymphatic node involvement, and ' $\mathrm{M}$ ' for metastasis. KPS: Karnofsky Performance Status; ECOG: Eastern Cooperative Oncology Group Performance Status; TM: Traditional medicine. 5-FU: 5-Fluorouracil; LV: Leucovorin; Ox.: Oxaliplatin; Xel: Capecitabine; FOLFOX: Ox. + 5-FU + LV; XELOX: Ox. + Capecitabine; ACRC: advanced colorectal cancer; bid: twice per day; tid: three times per day; qd: once per day; wk: week; mth: month; med.: median. 
Table 2. Meta-analysis results for CIN (FN, grades 4, 3, 3/4, 1/2, all grades), Neutrophil count and Tumour response rate

\begin{tabular}{|c|c|c|c|c|c|}
\hline Group & $\begin{array}{l}\text { No. studies } \\
\text { (participant } \\
\text { No. T/C) } \\
\end{array}$ & Ref Nos. & 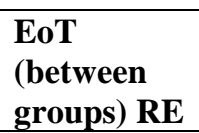 & $\mathbf{I}^{2}$ & $\begin{array}{l}\text { Incidence } \\
\text { T/C }(\%)\end{array}$ \\
\hline \multicolumn{6}{|c|}{ Outcome: CIN } \\
\hline \multicolumn{6}{|c|}{ 1. Injection group (no G-CSF): 7 studies } \\
\hline Gr 4 & $1(65 / 52)$ & 48 & $\begin{array}{l}0.27[0.01, \\
6.44], p= \\
0.42\end{array}$ & NA & $\begin{array}{l}\text { T: } 0 \% \\
(0 / 65) ; \\
\text { C: } 1.9 \% \\
(1 / 52) \\
\end{array}$ \\
\hline Gr 3 & $4(199 / 186)$ & $46-48,51$ & $\begin{array}{l}0.62[0.28 \\
1.40], p= \\
0.25\end{array}$ & 0 & $\begin{array}{l}\mathrm{T}: 4.5 \% \\
(9 / 199) ; \\
\mathrm{C}: 7.5 \% \\
(14 / 186)\end{array}$ \\
\hline $\mathrm{Gr} 3 / 4$ & $5(221 / 207)$ & $46-48,50,51$ & $\begin{array}{l}0.47[0.22 \\
0.98], p= \\
0.04 *\end{array}$ & 0 & $\begin{array}{l}\mathrm{T}: 4.5 \% \\
(10 / 221) \\
\mathrm{C}: 11.1 \% \\
(23 / 207)\end{array}$ \\
\hline $\operatorname{Gr} 1 / 2$ & $4(199 / 186$ & $46-48,51$ & $\begin{array}{l}0.58[0.44 \\
0.77], \mathrm{p}= \\
0.0001^{*}\end{array}$ & 0 & $\begin{array}{l}\text { T: } 26.1 \% \\
(52 / 199) \\
\text { C: } 46.2 \% \\
(86 / 186)\end{array}$ \\
\hline All grades & $6(269 / 252)$ & $38,46-51$ & $\begin{array}{l}0.65[0.55 \\
0.76], \mathrm{p}< \\
0.00001^{*}\end{array}$ & 0 & $\begin{array}{l}\text { T: } 37.9 \% \\
(102 / 269) ; \\
\text { C: } 61.5 \% \\
(155 / 252)\end{array}$ \\
\hline \multicolumn{6}{|c|}{ 2. Oral administration group (no G-CSF): 21 studies } \\
\hline FN & $1(44 / 45)$ & 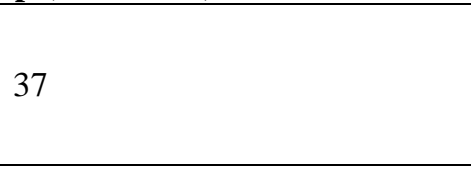 & $\begin{array}{l}0.20[0.01, \\
4.14], p= \\
0.30\end{array}$ & NA & $\begin{array}{l}\text { T: } 0 \% \\
\text { (0/44); } \\
\text { C: } 4.4 \% \\
(2 / 45) \\
\end{array}$ \\
\hline Gr 4 & $4(116 / 116)$ & $91,96,98,100$ & $\begin{array}{l}0.25[0.05 \\
1.18], p= \\
0.08\end{array}$ & 0 & $\begin{array}{l}\text { T: } 0 \% \\
(0 / 116) \\
\text { C: } 5.2 \% \\
(6 / 116)\end{array}$ \\
\hline Gr 3 & $15(509 / 462)$ & $39,40,84,85,87,88,91,92,94-100$ & $\begin{array}{l}0.37[0.21, \\
0.65], p= \\
0.0005^{*}\end{array}$ & 0 & $\begin{array}{l}\mathrm{T}: 3.1 \% \\
(16 / 509) \\
\mathrm{C}: 9.5 \% \\
(44 / 462)\end{array}$ \\
\hline Gr3/4 & $17(583 / 537)$ & $37,39,40,84,85,87,88,91-100$ & $\begin{array}{l}0.44[0.29 \\
0.66], \mathrm{p}= \\
0.0001^{*}\end{array}$ & 0 & $\begin{array}{l}\text { T: } 4.6 \% \\
(27 / 583) \\
\text { C: } 12.5 \% \\
(67 / 537)\end{array}$ \\
\hline $\operatorname{Gr} 1 / 2$ & $19(635 / 585)$ & $37,39,40,84-88,90-100$ & $\begin{array}{l}0.62[0.54 \\
0.72], \mathrm{p}< \\
0.00001^{*}\end{array}$ & 0 & $\begin{array}{l}\text { T: } 25.8 \% \\
(164 / 635) \\
\text { C: } 44.1 \% \\
(258 / 585)\end{array}$ \\
\hline All grades & $21(686 / 633)$ & $37,39,40,84-101$ & $\begin{array}{l}0.59[0.53, \\
0.67], \mathrm{p}< \\
0.00001^{*}\end{array}$ & 0 & $\begin{array}{l}\text { T: } 31.5 \% \\
(216 / 686) ; \\
\text { C: } 57.8 \% \\
(366 / 633)\end{array}$ \\
\hline \multicolumn{6}{|c|}{ Total: groups 1 and 2 (no G-CSF): 28 studies } \\
\hline Gr 4 & $5(181 / 168)$ & $48,91,96,98,100$ & $\begin{array}{l}0.26[0.06 \\
1.03], p= \\
0.05\end{array}$ & 0 & $\begin{array}{l}\text { T: } 0 \% \\
(0 / 181) \text {; } \\
\text { C: } 4.2 \% \\
\text { (7/168) }\end{array}$ \\
\hline
\end{tabular}




\begin{tabular}{|c|c|c|c|c|c|}
\hline Gr 3 & $19(708 / 647)$ & $\begin{array}{l}39,40,46- \\
48,51,84,85,87,88,91,92,94-100\end{array}$ & $\begin{array}{l}0.42[0.27 \\
0.67], \mathrm{p}= \\
0.0002^{*}\end{array}$ & 0 & $\begin{array}{l}\text { T: } 3.5 \% \\
(25 / 708) \\
\text { C: } 9.6 \% \\
(62 / 647)\end{array}$ \\
\hline $\mathrm{Gr} 3 / 4$ & $22(804 / 743)$ & $\begin{array}{l}37,39,40,46- \\
48,50,51,84,85,87,88,91-100\end{array}$ & $\begin{array}{l}0.45[0.31 \\
0.65], \mathrm{p}< \\
0.0001^{*}\end{array}$ & 0 & $\begin{array}{l}\text { T: } 4.6 \% \\
(37 / 804) ; \\
\text { C: } 11.8 \% \\
(88 / 743)\end{array}$ \\
\hline Gr1/2 & $23(834 / 771)$ & $37,39,40,46-48,51,84-88,90-100$ & $\begin{array}{l}0.61[0.54 \\
0.70], \mathrm{p}< \\
0.00001 *\end{array}$ & 0 & $\begin{array}{l}\text { T: } 25.9 \% \\
(216 / 834) ; \\
\text { C: } 43.3 \% \\
(334 / 771)\end{array}$ \\
\hline All grades & $27(955 / 885)$ & $37-39,40,46-49,51,84-101$ & $\begin{array}{l}0.61[0.56 \\
0.67], \mathrm{p}< \\
0.00001 *\end{array}$ & 0 & $\begin{array}{l}\text { T: } 33.3 \% \\
(318 / 955) \text {; } \\
\text { C: } 58.9 \% \\
(521 / 885)\end{array}$ \\
\hline \multicolumn{6}{|c|}{ 3. G-CSF group: 2 studies } \\
\hline Grade 3/4 & $2(66 / 63)$ & 33,34 & $\begin{array}{l}1.00[0.15, \\
6.63], \mathrm{p} \\
=1.00\end{array}$ & 0 & $\begin{array}{l}\mathrm{T}: 3.0 \% \\
(2 / 66) ; \\
\mathrm{C}: 3.2 \% \\
(2 / 63)\end{array}$ \\
\hline All grades & $2(66 / 63)$ & 33,34 & $\begin{array}{l}0.91[0.48, \\
1.74], \mathrm{p} \\
=0.78\end{array}$ & 27 & $\begin{array}{l}\text { T: } 36.3 \% \\
(24 / 66) ; \\
\text { C: } 38.1 \% \\
(24 / 63)\end{array}$ \\
\hline \multicolumn{6}{|c|}{ 4. Neutrophil count: 2 studies } \\
\hline $\begin{array}{l}\text { Total } \\
\text { neutrophils } \\
\text { (MD) }\end{array}$ & $2(122 / 90)$ & 35,36 & $\begin{array}{l}\text { MD: } 1.62 \\
{[0.93,2.32],} \\
p< \\
0.00001 *\end{array}$ & 66 & NA \\
\hline \multicolumn{6}{|c|}{ Outcome: Tumour response rate (tRR)for studies included in CIN groups ${ }^{1}$} \\
\hline \multicolumn{6}{|c|}{ 1. Injection group (no G-CSF): 6 studies that reported CIN data for Grade 3/4 and/or all grades } \\
\hline $\begin{array}{l}\text { Reported } \\
\text { CINGr3/4 }\end{array}$ & $4(191 / 177)$ & $47,48,50,51$ & $\begin{array}{l}1.43[1.04, \\
1.96], p= \\
0.03 *\end{array}$ & 37 & $\begin{array}{l}\text { T: } 52.4 \% \\
(100 / 191) \text {; } \\
\text { C: } 35.0 \% \\
(62 / 177)\end{array}$ \\
\hline $\begin{array}{l}\text { Reported } \\
\text { CIN all } \\
\text { grades }\end{array}$ & $5(239 / 222)$ & $38,47,48,49,51$ & $\begin{array}{l}1.38[1.07 \\
1.78], \mathrm{p}= \\
0.01 *\end{array}$ & 27 & $\begin{array}{l}\text { T: } 51.9 \% \\
(124 / 239) \text {; } \\
\text { C: } 36.5 \% \\
(81 / 222)\end{array}$ \\
\hline \multicolumn{6}{|c|}{ 2. Oral administration group(no G-CSF): 17 studies } \\
\hline $\begin{array}{l}\text { Reported } \\
\text { CIN Gr3/4 }\end{array}$ & $16(534 / 482)$ & $37,39,40,84,85,87,88,91-97,99,100$ & $\begin{array}{l}1.21[1.03, \\
1.42], \mathrm{p}= \\
0.02 *\end{array}$ & 0 & $\begin{array}{l}\text { T: 40.3\% } \\
(215 / 534) ; \\
\text { C: } 33.0 \% \\
(159 / 482)\end{array}$ \\
\hline $\begin{array}{l}\text { Reported } \\
\text { CIN all } \\
\text { grades }\end{array}$ & $17(569 / 514)$ & $37,39,40,84,85,87,88,91-97,99-101$ & $\begin{array}{l}1.20[1.03, \\
1.41], \mathrm{p}= \\
0.02 *\end{array}$ & 0 & $\begin{array}{l}\text { T: } 40.6 \% \\
(231 / 569) ; \\
\text { C: } 33.5 \% \\
(172 / 514)\end{array}$ \\
\hline \multicolumn{6}{|c|}{ Total for groups 1 and 2 (no G-CSF): 23 studies } \\
\hline $\begin{array}{l}\text { Reported } \\
\text { CIN Gr3/4 }\end{array}$ & $20(725 / 659)$ & $\begin{array}{l}37,39,40,47,48,50,51,84,85,87,88,91- \\
97,99,100\end{array}$ & $\begin{array}{l}1.29[1.13 \\
1.48], \mathrm{p}= \\
0.0002^{*}\end{array}$ & 0 & $\begin{array}{l}\text { T: } 43.4 \% \\
(315 / 725) \text {; } \\
\text { C: } 33.5 \% \\
(221 / 659)\end{array}$ \\
\hline $\begin{array}{l}\text { Reported } \\
\text { CIN all } \\
\text { grades }\end{array}$ & $23(832 / 759)$ & $37-40,47-49,51,84-88,91-97,99-101$ & $\begin{array}{l}1.27[1.13 \\
1.44], \mathrm{p}= \\
0.0001^{*}\end{array}$ & 0 & $\begin{array}{l}\mathrm{T}: 44.6 \% \\
(371 / 832) \text {; } \\
\mathrm{C}: 34.9 \% \\
(265 / 759)\end{array}$ \\
\hline
\end{tabular}




\begin{tabular}{|c|c|c|c|c|c|}
\hline \multicolumn{6}{|c|}{ 3. G-CSF group: 1 study } \\
\hline $\begin{array}{l}\text { Reported } \\
\text { CIN Grade } \\
3 / 4 \& \text { all } \\
\text { grades }\end{array}$ & $1(48 / 45)$ & 34 & $\begin{array}{l}1.16[0.77, \\
1.74], \\
p=0.47\end{array}$ & & $\begin{array}{l}\text { T: } 54.2 \% \\
(26 / 48) ; \\
\text { C:46.7\% } \\
(21 / 45)\end{array}$ \\
\hline \multicolumn{6}{|c|}{ 4. Neutrophil count: 2 studies } \\
\hline $\begin{array}{l}\text { Did not } \\
\text { report CIN } \\
\text { grades }\end{array}$ & $2(122 / 90)$ & 35,36 & $\begin{array}{l}1.24[0.92, \\
1.66], \\
p=0.16\end{array}$ & 0 & $\begin{array}{l}\text { T: } 52.5 \% \\
(64 / 122) ; \\
\text { C:42.2\% } \\
(38 / 90)\end{array}$ \\
\hline
\end{tabular}

T: treatment group; C control group; EoT: end of treatment; * significant at $\mathrm{p}<0.05$

1. included studies reported both CIN data for Grade 3/4 and/or all grades plus data for tumour response rate. 
Table 3: Effects of specific TMs on CIN (all grades): single TMs and combinations

\begin{tabular}{|c|c|c|c|c|c|c|}
\hline Level & Traditional Medicine (TM) & $\mathbf{R R}$ & $95 \% \mathrm{CI}$ & N. stud. Refs. & $\begin{array}{l}\text { N. } \\
\text { part. }\end{array}$ & $\mathbf{I}^{2}$ \\
\hline 1 & $\begin{array}{l}\text { Angelica sinensis(Oliv.) Diels. (dang } \\
\text { gui) }\end{array}$ & 0.38 & {$[0.22,0.64]$} & $2^{[85,98]}$ & 118 & 0 \\
\hline 1 & $\begin{array}{l}\text { Ligusticum chuanxiong Hort. (chuan } \\
\text { xiong) }\end{array}$ & 0.38 & {$[0.22,0.66]$} & $2^{[85,89]}$ & 114 & 0 \\
\hline 1 & Glycyrrhiza uralensis Fisch. (gan cao) & 0.40 & {$[0.27,0.60]$} & $3^{[85,94,101]}$ & 178 & 0 \\
\hline 1 & $\begin{array}{l}\text { Amomum kravanh Pierre ex. Gagnep. } \\
\text { (bai dou kou) }\end{array}$ & 0.41 & {$[0.26,0.65]$} & $2^{[95,101]}$ & 126 & 0 \\
\hline 1 & $\begin{array}{l}\text { Pinellia ternata (Thunb.) Breit. (ban } \\
\text { xia) }\end{array}$ & 0.45 & {$[0.31,0.64]$} & $3^{[94,95,98]}$ & 186 & 0 \\
\hline 1 & Smilax glabra Roxb. (tu fu ling) & 0.46 & {$[0.27,0.80]$} & $2^{[91,98]}$ & 121 & 0 \\
\hline 1 & Citrus reticulata Blanco (chen pi) & 0.46 & {$[0.29,0.72]$} & $2^{[86,94]}$ & 120 & 0 \\
\hline 1 & Eclipta prostrata L. (mo han lian) & 0.47 & {$[0.29,0.75]$} & $2^{[88,101]}$ & 138 & 0 \\
\hline 1 & Paeonia lactifloraalba. (bai shao) & 0.47 & {$[0.34,0.65]$} & $4^{[85,92,95,99]}$ & 212 & 0 \\
\hline 1 & $\begin{array}{l}\text { Sparganium stoloniferum Buch.- } \\
\text { Hamil. (san leng) }\end{array}$ & 0.47 & {$[0.27,0.81]$} & $2^{[89,93]}$ & 132 & 0 \\
\hline 1 & $\begin{array}{l}\text { Spatholobus suberectus Dunn (ji xue } \\
\text { teng) }\end{array}$ & 0.48 & {$[0.34,0.68]$} & $3^{[94,98,99]}$ & 192 & 0 \\
\hline 1 & $\begin{array}{l}\text { Actinidia arguta (Sieb. \& Zucc) } \\
\text { Planch. ex Miq. (teng li gen) }\end{array}$ & 0.49 & {$[0.29,0.84]$} & $2^{[92,98]}$ & 108 & 0 \\
\hline 1 & Smilax china L. (ba qia) & 0.49 & {$[0.30,0.81]$} & $2^{[91,94]}$ & 113 & 0 \\
\hline 1 & Poria cocos $(\mathrm{Sch} w)$ Wolf (fu ling) & 0.50 & {$[0.42,0.60]$} & $13^{[37,39,85,86,89,91-95,98,99,101]}$ & 780 & 0 \\
\hline 1 & Ligustrum lucidum Ait. (nu zhen zi) & 0.51 & {$[0.33,0.79]$} & $2^{[88,94]}$ & 130 & 0 \\
\hline 1 & $\begin{array}{l}\text { Curcuma zedoaria (Berg.) Rosc. or } C \text {. } \\
\text { phaeocaulis Val. (e zhu) }\end{array}$ & 0.51 & {$[0.38,0.67]$} & $6^{[88,89,91,93,94,99]}$ & 379 & 0 \\
\hline 1 & $\begin{array}{l}\text { Panax notoginseng (Burk.) F.H. Chen } \\
\text { (san qi) }\end{array}$ & 0.51 & {$[0.36,0.72]$} & $4^{[87,88,93,94]}$ & 245 & 0 \\
\hline 1 & Lycium barbarum L. (gou qi zi) & 0.52 & {$[0.38,0.71]$} & $3^{[39,88,94]}$ & 168 & 0 \\
\hline 1 & $\begin{array}{l}\text { Akebia quinata (Thunb.) Decne. (ba } \\
\text { yue zha) }\end{array}$ & 0.52 & {$[0.38,0.72]$} & $5^{[88,91,92,94,100]}$ & 264 & 0 \\
\hline 1 & Dioscorea opposita Thunb. (shan yao) & 0.52 & {$[0.39,0.71]$} & $4^{[37,85,95,99]}$ & 261 & 4 \\
\hline 1 & $\begin{array}{l}\text { Curcuma wenyujin } \mathrm{Y} . \mathrm{H} \text {. Chen et C. } \\
\text { Ling (yu jin) }\end{array}$ & 0.53 & {$[0.36,0.79]$} & $2^{[39,91]}$ & 91 & 0 \\
\hline 1 & $\begin{array}{l}\text { Vitis quinquangularis Rehd. (ye pu } \\
\text { tao teng) }\end{array}$ & 0.53 & {$[0.38,0.73]$} & $4^{[91,94,99,100]}$ & 218 & 0 \\
\hline 1 & $\begin{array}{l}\text { Codonopsis pilosula (Franch.). Nannf. } \\
\text { (dang shen) }\end{array}$ & 0.54 & {$[0.45,0.65]$} & $10^{[39,86,89,91-94,96,99,101]}$ & 615 & 0 \\
\hline 1 & $\begin{array}{l}\text { Astragalus membranaceus (Fisch.) } \\
\text { Bge. (huang qi) }\end{array}$ & 0.55 & {$[0.47,0.65]$} & $12^{[39,86,88-91,93,94,97,98,100,101]}$ & 682 & 0 \\
\hline 1 & Coix lacryma-jobi L. (yi ren) & 0.56 & {$[0.48,0.66]$} & $13^{[39,40,85,86,88,91,93-95,97,98,101]}$ & 773 & 0 \\
\hline 1 & $\begin{array}{l}\text { Epimedium brevicornum } \\
\text { Maxim(yinyanghuo) }\end{array}$ & 0.57 & {$[0.43,0.77]$} & $4^{[39,40,91,94]}$ & 271 & 0 \\
\hline 1 & $\begin{array}{l}\text { Atractylodes macrocephala Koidz. } \\
\text { (bai zhu) }\end{array}$ & 0.57 & {$[0.50,0.66]$} & $15^{[39,85,86,88,89,91-94,96-101]}$ & 962 & 0 \\
\hline 1 & $\begin{array}{l}\text { Scutellaria barbataD. Don. (ban zhi } \\
\text { lian) }\end{array}$ & 0.61 & {$[0.50,0.74]$} & $6^{[39,86,88,93,94,97]}$ & 356 & 0 \\
\hline 1 & Hedyotis diffusa Willd. (she she cao) & 0.63 & {$[0.51,0.79]$} & $5^{[86,92-94,97]}$ & 288 & 0 \\
\hline 1 & Agrimonia pilosa Ledeb. (xian he cao) & 0.65 & {$[0.48,0.88]$} & $2^{[88,96]}$ & 170 & 0 \\
\hline 2 & Poria + Coix & 0.46 & {$[0.37,0.57]$} & $9^{[39,85,86,91,93-95,98,101]}$ & 523 & 0 \\
\hline 2 & Poria + Atractylodes & 0.47 & {$[0.39,0.57]$} & $11^{[39,85,86,88,91-94,98,99,101]}$ & 633 & 0 \\
\hline 2 & Paeonia + Poria & 0.47 & {$[0.34,0.65]$} & $4^{[85,92,95,99]}$ & 212 & 0 \\
\hline 2 & Vitis + Atractylodes & 0.50 & {$[0.36,0.70]$} & $4^{[91,94,99,100]}$ & 218 & 0 \\
\hline 2 & C. zedoaria + Atractylodes & 0.51 & {$[0.38,0.67]$} & $6^{[88,89,91,93,94,99]}$ & 379 & 0 \\
\hline 2 & Akebia + Atractylodes & 0.52 & {$[0.38,0.72]$} & $5^{[88,91,92,94,100]}$ & 264 & 0 \\
\hline 2 & Poria + Dioscorea & 0.52 & {$[0.39,0.71]$} & $4^{[37,85,95,99]}$ & 261 & 4 \\
\hline 2 & Codonopsis + Atractylodes & 0.54 & {$[0.45,0.65]$} & $10^{[39,86,89,91-94,96,99,101]}$ & 615 & 0 \\
\hline 2 & Coix + Atractylodes & 0.56 & {$[0.47,0.67]$} & $10^{[39,85,86,88,91,93,94,97,98,101]}$ & 595 & 0 \\
\hline 2 & Astragalus + Atractylodes & 0.56 & {$[0.48,0.67]$} & $11^{[39,86,88,89,91,93,94,97,98,100,101]}$ & 650 & 0 \\
\hline 2 & Epimedium + Coix & 0.57 & {$[0.43,0.77]$} & $44^{[39,40,91,94]}$ & 271 & 0 \\
\hline
\end{tabular}




\begin{tabular}{|c|c|c|c|c|c|c|}
\hline 2 & Atractylodes + Hedyotis & 0.63 & {$[0.51,0.79]$} & $5^{[86,92-94,97]}$ & 288 & 0 \\
\hline 2 & Agrimonia + Atractylodes & 0.65 & {$[0.48,0.88]$} & $2^{[88,96]}$ & 170 & 0 \\
\hline 3 & Poria + Atractylodes + Ligusticum & 0.38 & {$[0.22,0.66]$} & $2^{[85,89]}$ & 114 & 0 \\
\hline 3 & Poria + Coix + Amomum & 0.41 & {$[0.26,0.65]$} & $2^{[91,101]}$ & 126 & 0 \\
\hline 3 & Poria + Coix + Pinellia & 0.45 & {$[0.31,0.64]$} & $3^{[94,96,98]}$ & 186 & 0 \\
\hline 3 & Poria + Dioscorea + Paeonia & 0.45 & {$[0.32,0.64]$} & $3^{[85,90,99]}$ & 172 & 0 \\
\hline 3 & Poria + Coix + Atractylodes & 0.46 & {$[0.37,0.59]$} & $8^{[39,85,86,91,93,94,98,101]}$ & 465 & 0 \\
\hline 3 & Poria + Astragalus + Smilax glabra & 0.46 & {$[0.27,0.80]$} & $2^{[91,98]}$ & 121 & 0 \\
\hline 3 & Poria + Atractylodes + Astragalus & 0.47 & {$[0.38,0.60]$} & $8^{[39,86,89,91,93,94,98,101]}$ & 479 & 0 \\
\hline 3 & Poria + Coix + Astragalus & 0.48 & {$[0.37,0.61]$} & $7^{[39,86,91,93,94,98,92101]}$ & 415 & 0 \\
\hline 3 & Spatholobus + Poria + Atractylodes & 0.48 & {$[0.34,0.68]$} & $3^{[94,98,99]}$ & 192 & 0 \\
\hline 3 & Poria + Atractylodes + Paeonia & 0.48 & {$[0.33,0.71]$} & $3^{[85,92,99]}$ & 154 & 0 \\
\hline 3 & Poria + Atractylodes + Actinidia & 0.49 & {$[0.29,0.84]$} & $2^{[92,98]}$ & 108 & 0 \\
\hline 3 & Poria + Atractylodes + Codonopsis & 0.50 & {$[0.40,0.62]$} & $9^{[39,86,89,91-94,99,101]}$ & 515 & 0 \\
\hline 3 & $\begin{array}{l}\text { Astragalus + Atractylodes + C. } \\
\text { zedoarea }\end{array}$ & 0.50 & {$[0.36,0.69]$} & $5^{[88,89,91,93,94]}$ & 315 & 0 \\
\hline 3 & Astragalus + Atractylodes + Akebia & 0.51 & {$[0.35,0.72]$} & $4^{[88,91,94,100]}$ & 224 & 0 \\
\hline 3 & Coix + Atractylodes + Astragalus & 0.58 & {$[0.48,0.69]$} & $9^{[39,86,88,91,93,94,97,98,101]}$ & 545 & 0 \\
\hline 4 & $\begin{array}{l}\text { Poria + Atractylodes }+ \text { Angelica }+ \\
\text { Coix }\end{array}$ & 0.38 & {$[0.22,0.64]$} & $2^{[85,98]}$ & 118 & 0 \\
\hline 4 & $\begin{array}{l}\text { Poria + Atractylodes + Glycyrrhiza + } \\
\text { Coix }\end{array}$ & 0.40 & {$[0.27,0.60]$} & $3^{[85,94,101]}$ & 178 & 0 \\
\hline 4 & $\begin{array}{l}\text { Paeonia + Dioscorea + Poria+ } \\
\text { Atractylodes }\end{array}$ & 0.45 & {$[0.29,0.71]$} & $2^{[86,99]}$ & 114 & 0 \\
\hline 4 & $\begin{array}{l}\text { Astragalus + Atractylodes + Coix }+ \\
\text { Eclipta }\end{array}$ & 0.47 & {$[0.29,0.75]$} & $2^{[88,101]}$ & 138 & 0 \\
\hline 4 & $\begin{array}{l}\text { Astragalus + Atractylodes }+ \text { Akebia }+ \\
\text { Vitis }\end{array}$ & 0.48 & {$[0.31,0.74]$} & $3^{[91,94,100]}$ & 154 & 0 \\
\hline 4 & $\begin{array}{l}\text { Codonopsis }+ \text { Astragalus }+ \\
\text { Atractylodes }+ \text { Poria }\end{array}$ & 0.48 & {$[0.38,0.62]$} & $7^{[39,86,89,91,93,94,101]}$ & 411 & 0 \\
\hline 4 & $\begin{array}{l}\text { C. zedoaria + Poria + Atractylodes }+ \\
\text { Codonopsis }\end{array}$ & 0.49 & {$[0.36,0.67]$} & $5^{[89,91,93,94,99]}$ & 309 & 0 \\
\hline 4 & $\begin{array}{l}\text { Poria }+ \text { Codonopsis }+ \text { Atractylodes }+ \\
\text { Hedyotis }\end{array}$ & 0.49 & {$[0.35,0.70]$} & $4^{[86,92-94]}$ & 228 & 0 \\
\hline 4 & $\begin{array}{l}\text { Astragalus }+ \text { Coix }+ \text { C. zedoaria }+ \\
\text { Atractylodes }\end{array}$ & 0.51 & {$[0.36,0.73]$} & $4^{[88,91,93,94]}$ & 251 & 0 \\
\hline 4 & $\begin{array}{l}\text { Codonopsis }+ \text { Atractylodes }+ \text { Poria }+ \\
\text { Akebia }\end{array}$ & 0.52 & {$[0.34,0.80]$} & $3^{[91,92,94]}$ & 153 & 0 \\
\hline 4 & $\begin{array}{l}\text { Paeonia }+ \text { Codonopsis }+ \text { Atractylodes } \\
+ \text { Poria }\end{array}$ & 0.55 & {$[0.35,0.86]$} & $2^{[92,99]}$ & 104 & 0 \\
\hline 4 & $\begin{array}{l}\text { Astragalus }+ \text { Coix }+ \text { Atractylodes }+ \\
\text { Scutellaria }\end{array}$ & 0.61 & {$[0.50,0.74]$} & $6^{[39,86,88,93,94,97]}$ & 356 & 0 \\
\hline 4 & $\begin{array}{l}\text { Astragalus + Atractylodes + Coix + } \\
\text { Hedyotis }\end{array}$ & 0.61 & {$[0.46,0.80]$} & $4^{[86,93,94,97]}$ & 248 & 0 \\
\hline 5 & $\begin{array}{l}\text { Astragalus + Atractylodes + Poria + } \\
\text { Smilax glabra + Coix }\end{array}$ & 0.46 & {$[0.27,0.80]$} & $2^{[91,98]}$ & 121 & 0 \\
\hline 5 & $\begin{array}{l}\text { Codonopsis + Poria + Astragalus + C. } \\
\text { zedoaria + Atractylodes }\end{array}$ & 0.48 & {$[0.33,0.70]$} & $4^{[89,91,93,94]}$ & 245 & 0 \\
\hline 5 & $\begin{array}{l}\text { Astragalus }+ \text { Coix }+ \text { Poria }+ \\
\text { Codonopsis }+ \text { Atractylodes }\end{array}$ & 0.49 & {$[0.37,0.63]$} & $6^{[39,86,91,92,94,101]}$ & 348 & 0 \\
\hline 5 & $\begin{array}{l}\text { Codonopsis }+ \text { Atractylodes }+ \text { Poria }+ \\
\text { C. zedoaria }+ \text { Vitis }\end{array}$ & 0.51 & {$[0.35,0.73]$} & $3^{[91,94,99]}$ & 177 & 0 \\
\hline 5 & $\begin{array}{l}\text { Atractylodes }+ \text { Hedyotis }+ \text { Akebia }+ \\
\text { Poria }+ \text { Codonopsis }\end{array}$ & 0.52 & {$[0.32,0.84]$} & $2^{[92,94]}$ & 100 & 0 \\
\hline 5 & $\begin{array}{l}\text { Astragalus + Coix + Atractylodes }+\mathrm{C} . \\
\text { zedoaria }+ \text { Akebia }\end{array}$ & 0.52 & {$[0.35,0.76]$} & $3^{[88,91,94]}$ & 183 & 0 \\
\hline 5 & $\begin{array}{l}\text { Lycium + Atractylodes + Coix }+ \\
\text { Astragalus }+ \text { Scutellaria }\end{array}$ & 0.53 & {$[0.39,0.73]$} & $3^{[39,88,94]}$ & 168 & 0 \\
\hline 5 & $\begin{array}{l}\text { Atractylodes + Astragalus + Coix }+ \\
\text { Hedyotis }+ \text { Scutellaria }\end{array}$ & 0.61 & {$[0.46,0.80]$} & $4^{[86,93,94,97]}$ & 248 & 15 \\
\hline 6 & $\begin{array}{l}\text { Codonopsis + Astragalus + Coix + } \\
\text { Glycyrrhiza + Atractylodes + Poria }\end{array}$ & 0.43 & {$[0.27,0.68]$} & $2^{[94,101]}$ & 128 & 0 \\
\hline 6 & $\begin{array}{l}\text { Astragalus + Coix + Poria + Pinellia + } \\
\text { Spatholobus + Atractylodes }\end{array}$ & 0.45 & {$[0.28,0.72]$} & $2^{[943,98]}$ & 128 & 0 \\
\hline
\end{tabular}




\begin{tabular}{|c|c|c|c|c|c|c|}
\hline 6 & $\begin{array}{l}\text { Hedyotis + Scutellaria + Coix }+ \\
\text { Codonopsis }+ \text { Astragalus + Poria }\end{array}$ & 0.47 & {$[0.32,0.69]$} & $3^{[86,93,94]}$ & 188 & 0 \\
\hline 6 & $\begin{array}{l}\text { Astragalus + Atractylodes + Poria + } \\
\text { Codonopsis + C. zedoaria }+ \\
\text { Sparganium }\end{array}$ & 0.47 & {$[0.27,0.81]$} & $2^{[89,93]}$ & 132 & 0 \\
\hline 6 & $\begin{array}{l}\text { Codonopsis + Atractylodes }+ \\
\text { Astragalus }+ \text { Coix }+ \text { Poria }+ \\
\text { Scutellaria }\end{array}$ & 0.50 & {$[0.37,0.68]$} & $4^{[39,86,93,94]}$ & 226 & 0 \\
\hline 6 & $\begin{array}{l}\text { Astragalus }+ \text { Atractylodes }+ \text { Poria }+ \\
\text { Codonopsis }+ \text { Coix }+ \text { C. } z \text { zedoaria }\end{array}$ & 0.50 & {$[0.33,0.75]$} & $3^{[91,93,94]}$ & 181 & 0 \\
\hline 6 & $\begin{array}{l}\text { Codonopsis + Atractylodes + Poria + } \\
\text { C.zedoaria + Vitis + Spatholobus }\end{array}$ & 0.50 & {$[0.33,0.75]$} & $2^{[94,99]}$ & 124 & 0 \\
\hline 6 & $\begin{array}{l}\text { C.zedoaria + Astragalus }+ \\
\text { Atractylodes }+ \text { Coix }+ \text { Panax }+ \\
\text { Scutellaria }\end{array}$ & 0.51 & {$[0.35,0.74]$} & $3^{[88,93,94]}$ & 198 & 0 \\
\hline 6 & $\begin{array}{l}\text { Codonopsis + Poria + Atractylodes + } \\
\text { Coix + Astragalus + Epimedium }\end{array}$ & 0.53 & {$[0.37,0.83]$} & $3^{39,91,94}$ & 152 & 0 \\
\hline 7 & $\begin{array}{l}\text { Astragalus }+ \text { Coix }+ \text { Codonopsis }+ \\
\text { Poria }+ \text { Atractylodes }+ \text { C. } \text { wenyujin }+ \\
\text { Epimedium }\end{array}$ & 0.55 & {$[0.37,0.83]$} & $2^{[39,91]}$ & 91 & 0 \\
\hline 8 & $\begin{array}{l}\text { Scutellaria + Hedyotis + Codonopsis } \\
+ \text { Atractylodes + Poria + Astragalus + } \\
\text { Coix + Citrus }\end{array}$ & 0.46 & {$[0.29,0.72]$} & $2^{[86,94]}$ & 120 & 0 \\
\hline 8 & $\begin{array}{l}\text { Codonopsis + Poria + Atractylodes + } \\
\text { Coix + Astragalus + Lycium }+ \\
\text { Scutellaria + Epimedium } \\
\end{array}$ & 0.53 & {$[0.36,0.76]$} & $2^{[39,94]}$ & 98 & 0 \\
\hline 9 & $\begin{array}{l}\text { Scutellaria + Hedyotis + C.zedoaria + } \\
\text { Codonopsis + Atractylodes }+ \\
\text { Astragalus + Poria + Coix }+ \text { Panax }\end{array}$ & 0.48 & {$[0.30,0.78]$} & $2^{[93,94]}$ & 128 & 0 \\
\hline 9 & $\begin{array}{l}\text { Ligustrum + Panax + C. zedoaria + } \\
\text { Akebia + Scutellaria + Lycium + Coix } \\
+ \text { Atractylodes + Astragalus }\end{array}$ & 0.51 & {$[0.33,0.79]$} & $2^{[88,94]}$ & 130 & 0 \\
\hline 10 & $\begin{array}{l}\text { Akebia + C. zedoaria + Vitis + Coix + } \\
\text { Atractylodes }+ \text { Astragalus }+ \\
\text { Codonopsis + Poria }+ \text { Smilax china }+ \\
\text { Epimedium }\end{array}$ & 0.49 & {$[0.30,0.81]$} & $2^{[91,94]}$ & 113 & 0 \\
\hline
\end{tabular}

RR: risk ratio; part.: participants; CI: confidence interval; stud.: studies.

Notes: Full botanical names are provided for level 1 with Chinese pin yin names in parentheses. Genus names are used for subsequent levels with abbreviated botanical name being used when clarity is required. RRs are listed in ascending order for each level. Lower RRs are associated with greater reductions in risk. Data with no significant effect or heterogeneity greater than $30 \%$ have been excluded 